University of New Hampshire

University of New Hampshire Scholars' Repository

Law Faculty Scholarship

University of New Hampshire - Franklin Pierce

School of Law

$1-1-2010$

\title{
A Fourth Amendment for the Poor Alone: Subconstitutional Status and the Myth of the Inviolate Home
}

Jordan C. Budd

University of New Hampshire School of Law

Follow this and additional works at: https://scholars.unh.edu/law_facpub

Part of the Fourth Amendment Commons, Other Public Affairs, Public Policy and Public

Administration Commons, Privacy Law Commons, Social Welfare Commons, and the Social Welfare Law

Commons

Comments

Abstract available at http://ssrn.com/abstract=1687938

\section{Recommended Citation}

Jordan C. Budd, "A Fourth Amendment for the Poor Alone: Subconstitutional Status and the Myth of the Inviolate Home," 85 IND. L.J. 355 (2010).

This Article is brought to you for free and open access by the University of New Hampshire - Franklin Pierce School of Law at University of New Hampshire Scholars' Repository. It has been accepted for inclusion in Law Faculty Scholarship by an authorized administrator of University of New Hampshire Scholars' Repository. For more information, please contact sue.zago@law.unh.edu. 


\title{
A Fourth Amendment for the Poor Alone: Subconstitutional Status and the Myth of the Inviolate Home
}

\author{
JORDAN C. BUDD*
}

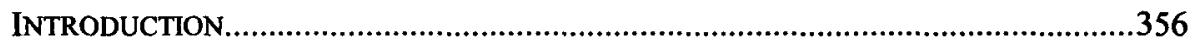

I. Selective SANCTITY: THE HoME, THE POOR, AND THE INTRUSIVE STATE ..........358

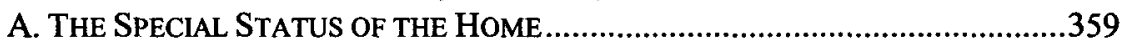

B. THE HOMES OF THE POOR: A COMPETING NARRATIVE..............................363

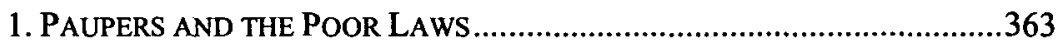

2. UNFIT HOMES AND FRIENDLY VISITORS..........................................366

C. WYMAN V. JAMES: RESOLVING THE CONFLICT IN FAVOR OF THE STATE ........368

II. ABANDONING PRETENSE: THE CONTEMPORARY APPLICATION OF WYMAN..........373

A. BACK TO THE FUTURE: WELFARE REFORM AND THE INTRUSIVE STATE......375

1. ENDING WELFARE AS WE KNOW IT ...............................................375

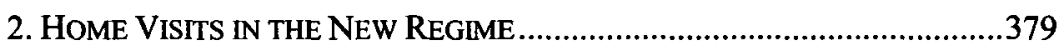

B. CONSTITUTIONALIZING THE MODERN HOME VISIT .....................................385

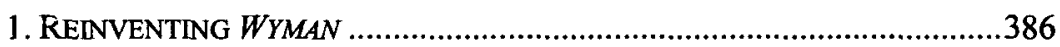

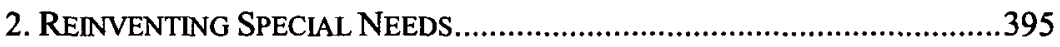

C. MAKING SENSE OF NONSENSE: The POOR AS A SubCONSTTtuTIONAL

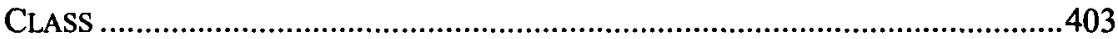

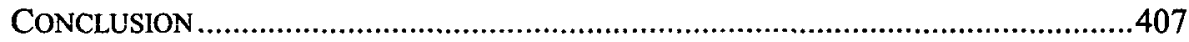

For much of our nation's history, the poor have faced pervasive discrimination in the exercise of fundamental rights. Nowhere has the impairment been more severe than in the area of privacy. This Article considers the enduring legacy of this tradition with respect to the Fourth Amendment right to domestic privacy. Far from a matter of receding historical interest, the diminution of the poor's right to privacy has accelerated in recent years and now represents a powerful theme within the jurisprudence of poverty. Triggering this development has been a series of challenges to aggressive administrative practices adopted by localities in the wake of federal welfare-reform legislation. As a precondition to public assistance, some jurisdictions now require that all applicants submit to a suspicionless home search by lawenforcement investigators seeking evidence of welfare fraud. In turning back challenges to these intrusions, contemporary courts have significantly curtailed the protections of the Fourth Amendment as applied to the poor.

* Professor of Law, Franklin Pierce Law Center. Many thanks to my colleagues Sophie Sparrow, Mitchell Simon, and Margaret McCabe for their helpful suggestions and comments, and to my research assistants Peter Keane and Austin Padgett for the invaluable assistance that they offered throughout this project. Thanks also to Dean John Hutson and Associate Dean Susan Richey of the Franklin Pierce Law Center for their support and encouragement. Before joining the faculty of Pierce Law, I served as Legal Director of the ACLU Foundation of San Diego \& Imperial Counties and in that capacity represented the plaintiff class in Sanchez $v$. County of San Diego, one of the cases discussed below. In view of that earlier organizational affiliation, I emphasize that the views expressed here are solely my own. 
While the courts that sanction these practices disclaim any sort of poverty-based classification underlying their analysis, no other rationale withstands scrutiny. Neither precedent nor the principled extension of existing doctrine justifies recent outcomes or explains why the holdings should not be applied to authorize a vast-and, thus, unacceptable-expansion of suspicionless search practices directed at the homes of the less destitute. The developing jurisprudence accordingly represents an implicit concession that the poor constitute a subconstitutional class for purposes of the Fourth Amendment. Framed most charitably, the decisions understand poverty as a condition of moral culpability and thus accept it as a surrogate for the individualized suspicion that otherwise would be required to justify the intrusions at issue. The premise of the dissolute poor, tracing back centuries, remains alive and well in American law, and we have a bifurcated Fourth Amendment to prove its enduring vitality.

"You have to watch every step like you are in prison. All the time you are on welfare, yeah, you are in prison. Someone is watching like a guard."

\section{INTRODUCTION}

For much of our nation's history, the poor have faced pervasive discrimination in the exercise of fundamental rights. ${ }^{2}$ Nowhere has the impairment been more severe than in the area of privacy. ${ }^{3}$ Acting with the acquiescence of a complicit judiciary, the state has repeatedly exempted the poor from the full measure of privacy protections at the core of our constitutional identity-most often through the imposition of highly intrusive conditions upon the government's provision of subsistence aid or its recognition of the custodial interests of indigent parents. ${ }^{4}$

1. JoHn GILliom, OVERSEers of THE POOR: SURVEILlanCE, RESISTANCE, AND THE Limits OF PRIVACY 1 (2001) (quoting "Mary, a forty-something mother of three, on welfare, in Appalachian Ohio").

2. See, e.g., Julie A. Nice, No Scrutiny Whatsoever: Deconstitutionalization of Poverty Law, Dual Rules of Law, \& Dialogic Default, 35 FORDHAM URB. L.J. 629, 629-36 (2008); William P. Quigley, Reluctant Charity: Poor Laws in the Original Thirteen States, 31 U. RicH. L. REv. 111, 160 (1997) [hereinafter Quigley, Reluctant Charity] ("Needy persons [in the original states] were paupers, and as such they forfeited all civil, political, and social rights. They could be jailed, sold at auction, or indentured at the discretion of the individual towns or communities."); James G. Wilson, Reconstructing Section Five of the Fourteenth Amendment to Assist Impoverished Children, 38 CLEV. ST. L. REV. 391, 402-15 (1990) (discussing judicial reluctance to enforce interests of poor). See generally Ann M. Burkhart, The Constitutional Underpinnings of Homelessness, 40 Hous. L. REv. 211, 215 (2003) ("The poor have been largely disenfranchised and have been the subject of invidious discrimination.").

3. See, e.g., Naomi R. Cahn, Models of Family Privacy, 67 GEO. WASH. L. REv. 1225, 1243 (1999) ("The history of aid to poor women is replete with attempts to control their lives by making receipt of public welfare contingent on their compliance with morality requirements that also involve state supervision of their lives."); Jonathan L. Hafetz, "A Man's Home Is His Castle? ": Reflections on the Home, the Family, and Privacy During the Late Nineteenth and Early Twentieth Centuries, 8 WM. \& MARY J. WOMEN \& L. 175, 240-42 (2002).

4. See infra notes 51-93 and accompanying text. 
This Article considers the enduring legacy of this dark constitutional tradition with respect to the privacy interest perhaps most celebrated in the popular and judicial conception: the Fourth Amendment right to be secure in one's home absent good cause for government intrusion. ${ }^{5}$ Far from a matter of receding historical interest, the diminution of the poor's Fourth Amendment right to domestic privacy has accelerated in recent years and now represents a powerful theme within the jurisprudence of poverty. Triggering this development has been a series of legal challenges to increasingly aggressive administrative practices adopted by various localities in the wake of federal welfare-reform legislation. ${ }^{6}$ As a precondition to the provision of public assistance, some jurisdictions now require that applicants submit to an unannounced and suspicionless search of their homes by law-enforcement investigators seeking evidence of welfare fraud-a practice that pushes far beyond the verification requirements previously imposed on aid applicants. ${ }^{7}$ In turning back challenges to these privacy intrusions, courts have significantly curtailed the protections of the Fourth Amendment as applied to the poor.

While the courts that sanction these practices disclaim any sort of poverty-based classification underlying their analysis, this Article argues that no other rationale withstands scrutiny. Neither precedent nor the principled extension of existing Fourth Amendment doctrine justifies recent outcomes or explains why those holdings should not be applied to authorize a vast-and, thus, unacceptable-expansion of suspicionless search practices directed at the homes of the less destitute. The developing jurisprudence thus represents an implicit concession that the poor constitute a subconstitutional class for purposes of the Fourth Amendment and a confirmation that judicial bias continues to powerfully burden indigent litigants. Framed most charitably, the decisions understand poverty as a condition of moral culpability and thus accept it as a surrogate for the individualized suspicion of wrongdoing that otherwise would be required to justify the intrusions at issue. The premise of the guilty poor, tracing back centuries, remains very much alive and well in contemporary American law.

The Article is divided into two parts. Part I reviews the two powerful and competing themes at issue in the current debate over the permissibility of suspicionless home searches of the poor: the sanctity of the home in our constitutional tradition, and the contrasting historical exclusion of indigents from the full enjoyment of privacy rights at the core of our national self-conception. After briefly examining the exalted status of the home in American law and the long and competing history of state-sanctioned intrusions upon the domestic privacy of the poor, the Article turns to the most recent pronouncement by the United States Supreme Court on the subject-its 1971 decision

5. See, e.g., Silverman v. United States, 365 U.S. 505, 511 (1961) ("At the very core [of the Fourth Amendment] stands the right of a man to retreat into his own home and there be free from unreasonable governmental intrusion."); D. Benjamin Barros, Home as a Legal Concept, 46 SANTA CLARA L. REV. 255, 255 (2006) ("In the United States, home and home ownership are held in high cultural esteem, as American as apple pie and baseball ... . [W]e have developed something of an ideology of home where the protection of home and all it stands for is an American virtue.").

6. See infra notes 204-55 and accompanying text.

7. See infra notes 204-55 and accompanying text. 
in Wyman v. James, ${ }^{8}$ which sanctioned suspicionless home visits conducted by social workers as a condition of welfare assistance. ${ }^{9}$ Widely condemned by commentators and characterized as a limited aberration, ${ }^{10}$ Wyman has actually enlarged its reach over the last three decades as lower courts have repeatedly invoked its rationale to justify increasingly intrusive search practices targeting the homes of the poor. ${ }^{11}$

Part II examines the contemporary jurisprudence endorsing the constitutionality of aggressive search practices now being directed against the homes of welfare applicants. The decisions rest on two primary rationales: first, that the Supreme Court's holding in Wyman authorizes the practices, and, second, that the contemporary special-needs doctrine independently justifies the intrusions. Neither rationale is remotely persuasive. The searches at issue reach far beyond the conduct authorized by Wyman-which itself lacked any principled doctrinal basis to support the special burden it inflicted upon the poor-and they lack virtually all the essential attributes of the relatively narrow class of suspicionless searches sanctioned by the special-needs doctrine. In particular, the searches at issue here are designed to advance a need that is not special in any respect: the government's administrative interest in the fiscal integrity of a benefits program. If the government is justified in searching, without suspicion, the home of every applicant for public assistance simply to advance its mundane and general interest in preventing the improper expenditure of some of its funds, then it necessarily is justified in searching, again without suspicion, the home of every person claiming a benefit, $\operatorname{tax}$ credit, or deduction that depends in part on representations about conditions within the home. To state the proposition is to refute it.

In conclusion, the Article considers the implications of this jurisprudence in view of the collapse of its stated rationales. Presuming that the decisions do not represent a new and unparalleled doctrinal assault upon the constitutional protections afforded the homes of virtually all persons-an untenable proposition, given the practical impossibility of its implications - the conclusion is apparent that these cases instead lay bare the dual and discriminatory nature of the contemporary Fourth Amendment. Quite simply, the provision means two very different things, depending on the relative wealth of the person seeking its protection. It is a distinction made explicable, if at all, by the archaic notion that poverty reflects the personal culpability of those who endure it.

\section{SElective SANCTITY: THE Home, THE PoOR, AND the InTRusive STATE}

As John Gilliom notes, “'the poor' includes all races, colors, ethnicities, regions, and ages of people, although it is heavy on women and children. . . In short, those who at some period of time populate the low end of the income distribution scale in the United States are indescribably varied and multifaceted." ${ }^{12}$ While terms such as "the poor" and "the indigent" thus refer to a "complex and unwieldy reality," they nevertheless identify a shared economic condition-low income coupled with scarce material assets - that places individuals so described in a similar posture with respect
8. 400 U.S. 309 (1971).
9. Id. at 326 .
10. See infra notes $99-143$ and accompanying text.
11. See infra notes $260-331$ and accompanying text.
12. GILLIOM, supra note 1 , at 20-21.
13. Id. at 20. 
to the state, particularly when the terms are understood to more narrowly focus on persons in need of state assistance to meet subsistence needs. ${ }^{14}$ So defined, "the poor" identifies a class of individuals whose exercise of fundamental rights has been significantly compromised by their relationship with the state. ${ }^{15}$

The particular focus of this Article is the restricted ability of these poorunderstood specifically to include persons in need of public assistance-to exercise the Fourth Amendment's celebrated right to privacy within the home. At the core of the question are two conflicting narratives: the long and robust history of our right to sanctuary within the "castle" of our homes, and the very different story of the poor's enduring struggle against state-sanctioned intrusion. These themes collided in Wyman $v$. James, a decision addressing the degree to which the poor sacrifice rights of domestic privacy in exchange for public assistance. The Supreme Court's resolution of the question embraced longstanding biases against the poor, ignored competing values of domestic security, and set in motion a privacy jurisprudence that has grown increasingly hostile over the intervening three decades.

\section{A. The Special Status of the Home}

The home holds a privileged position in the Anglo-American legal tradition. ${ }^{16}$ English law recognized over four centuries ago that "the house of every one is to him as his ... castle and fortress, as well for his defence against injury and violence, as for his repose . . ."17 As James Otis summarized in his 1761 argument challenging the legality of the Writs of Assistance, "one of the most essential branches of English liberty is the freedom of one's house. A man's house is his castle; and whilst he is quiet, he is as well guarded as a prince in his castle." 18 The doctrine, at least in its later and perhaps idealized recounting, made no distinction between the rich and the poor, as William Pitt famously underscored in a 1763 speech to Parliament:

The poorest man may in his cottage bid defiance to all the forces of the Crown. It may be frail; its roof may shake; the wind may blow through it; the storm may

14. $C f$. DOuglas R. IMIG, Poverty and Power: THe Political RePresentation of POOR AMERICANS 2 (1996) ("The diversity of low-income Americans helps to explain the historical paucity of political action by the poor. To act as a group, poor people would need to see themselves as undergoing a common plight--yet they have little or no opportunity to recognize the shared aspects of their condition.").

15. See infra notes 51-143 and accompanying text.

16. See, e.g., District of Columbia v. Little, 178 F.2d 13, 16-17 (D.C. Cir. 1949) ("The common-law right of a man to privacy in his home [is] a right which is one of the indispensable ultimate essentials of our concept of civilization. It was firmly established in the common law as one of the bright features of the Anglo-Saxon contributions to human progress."), aff d on other grounds, 339 U.S. 1 (1950).

17. Semayne's Case, 77 Eng. Rep. 194, 195 (K.B. 1604); see also 4 WILlaA Blackstone, COMMENTARIES *223 ("[The law has] so particular and tender a regard to the immunity of a man's house that it stiles it his castle, and will never suffer it to be violated with impunity ....").

18. James Otis, Speech in the Cause of the Writs of Assistance (1761), in WILLIAM TUdor, THE LIFE OF JAMES OTIS, OF MASSACHUSETTS 62, 66-67 (1823); quoted in Frank v. Maryland, 359 U.S. 360, 379 (1959) (Douglas, J., dissenting), overruled by Camara v. Mun. Court, 387 U.S. 523 (1967). 
enter; the rain may enter; but the King of England cannot enter-all his force dares not cross the threshold of the ruined tenement! ${ }^{19}$

This principle "carried over with a nearly-sacred resolve to the American colonies" The Fourth Amendment's protection against unreasonable searches and seizures, as well as the Third Amendment's bar against the quartering of soldiers in private houses, reflect a foundational commitment to the "fierce protection of the inner sanctum of the home" 22 inherited from English law and bolstered by the colonists' bitter experience with the intrusive practices of the English crown. ${ }^{23}$ Notably, the colonists' objection to unreasonable search practices focused almost exclusively on the home; similar complaints were not made with respect to other forms of property such as ships, commercial establishments, and warehouses. ${ }^{24}$ The debates surrounding the ratification of the Constitution reflected a similar focus. ${ }^{25}$

This constitutional commitment took broader and more concrete form over the course of the late nineteenth and early twentieth centuries as the Court explicitly linked the Fourth Amendment's protection of property rights with the privacy interests affiliated with the home. ${ }^{26}$ In Boyd $v$. United States, ${ }^{27}$ decided in 1886, the Court stressed that the Fourth Amendment "affect[s] the very essence of constitutional liberty and security" and broadly applies "to all invasions on the part of the government and its employés of the sanctity of a man's home and the privacies of his life."28 Underscoring the reach of the provision, the Court declared:

It is not the breaking of his doors, and the rummaging of his drawers, that constitutes the essence of the offence; but it is the invasion of his indefeasible right of personal security, personal liberty and private property, where that right has never been forfeited by his conviction of some public offence ... ${ }^{29}$

Two decades later, in Weeks $v$. United States, ${ }^{30}$ the Supreme Court expanded the reach of the Fourth Amendment in additional and important respects by constitutionalizing the common law warrant requirement for home searches and by applying the

19. Miller v. United States, 357 U.S. 301, 307 (1958) (quoting William Pitt).

20. Ken Gormley, One Hundred Years of Privacy, 1992 WIS. L. REv. 1335, 1358.

21. See id. at 1358-59; Barros, supra note 5, at 265.

22. Gormley, supra note 20, at 1358.

23. See id. at 1358-59; see also Monroe v. Pape, 365 U.S. 167, 210 (1961) (Frankfurter, J., dissenting) ("Searches of the dwelling house were the special object of this universal condemnation of official intrusion [embodied by the common law and the American Constitution].").

24. Thomas Y. Davies, Rediscovering the Original Fourth Amendment, $98 \mathrm{MiCH}$. L. REv. $547,601-08$ (1999).

25. Id. at 609 .

26. Id. at 726; Gormley, supra note 20, at 1357-75; Hafetz, supra note 3, at 195.

27. 116 U.S. $616(1886)$.

28. Id. at 630 .

29. Id.

30. 232 U.S. 383 (1914). 
exclusionary rule to evidence obtained in violation of that requirement. ${ }^{31}$ Weeks thus firmly established the Fourth Amendment as "a broad protection of a right to be secure in one's house and papers rather than as a simple ban against general warrants." 32

Within the last fifty years, the Court has further expanded the reach of the Fourth Amendment by declaring that the provision protects people - not merely placesbased upon the individual's reasonable expectations of privacy. ${ }^{33}$ Under this doctrine, the home continues to enjoy unique status based on the heightened expectation of privacy that individuals reasonably possess within their dwelling ${ }^{34}$ as well as a continuing recognition of the historical fact that "the Fourth Amendment has drawn a firm line at the entrance to the house." ${ }^{35}$ Despite the Supreme Court's recent diminution of Fourth Amendment protections in other contexts, ${ }^{36}$ scores of contemporary authorities confirm the singular privacy protections enjoyed within the home. ${ }^{37}$ As the Second Circuit recently noted, the Fourth Amendment's "ultimate protection" applies in the home alone. ${ }^{38}$

As a consequence, the state faces significant constraints in breaching domestic privacy to advance the objectives of either the criminal or civil law. Most familiar is the requirement that the state ordinarily obtain a warrant issued on a showing of probable cause prior to entering a home for purposes of making an arrest or searching for evidence. ${ }^{39}$ In the absence of a warrant and probable cause, the government may not monitor activities within the home even by means as apparently unobtrusive as

31. Id. at 393, 398; Davies, supra note 24 , at $729-30$.

32. Davies, supra note 24, at 730-31; see also Gouled v. United States, 255 U.S. 298, 305 $06(1921)$.

33. See Katz v. United States, 389 U.S. 347, 353 (1967); id. at 360-61 (Harlan, J., concurring); see also, e.g., Kyllo v. United States, 533 U.S. 27, 33 (2001).

34. Kyllo, 533 U.S. at 34; see, e.g., Minnesota v. Carter, 525 U.S. 83, 99 (1998) (Kennedy, J., concurring) ("[I]t is beyond dispute that the home is entitled to special protection as the center of the private lives of our people.").

35. Payton v. New York, 445 U.S. 573, 590 (1980); see, e.g., Kyllo, 533 U.S. at 34; Wilson v. Layne, 526 U.S. 603, 610 (1999); United States v. U.S. Dist. Court (Keith), 407 U.S. 297, 313 (1972).

36. See, e.g., Tracey Maclin, The Central Meaning of the Fourth Amendment, 35 WM. \& MARY L. REV. 197 passim (1993).

37. See, e.g., Georgia v. Randolph, 547 U.S. 103, 115 (2006); Kyllo, 533 U.S. 27 passim; Wilson, 526 U.S. at 610; Carey v. Brown, 447 U.S. 455, 471 (1980); Payton, 445 U.S. at 590; Keith, 407 U.S. at 313; Silverman v. United States, 365 U.S. 505, 511 (1961); Monroe v. Pape, 365 U.S. 167, 210 (1961); Miller v. United States, 357 U.S. 301, 306-07 (1958); United States v. Gray, 491 F.3d 138, 144 (4th Cir. 2007); Doriane Lambelet Coleman, Storming the Castle to Save the Children: The Ironic Costs of a Child Welfare Exception to the Fourth Amendment, 47 WM. \& MARY L. REV. 413, 502 (2005) ("The law is clearest on official incursions into an individual's home.").

38. United States v. Haqq, 278 F.3d 44, 54 (2d Cir. 2002); see, e.g., Ferguson v. City of Charleston, 532 U.S. 67, 83 n.21 (2001); Payton, 445 U.S. at 589 ("The Fourth Amendment protects the individual's privacy in a variety of settings. In none is the zone of privacy more clearly defined than when bounded by the unambiguous physical dimensions of an individual's home-a zone that finds its roots in clear and specific constitutional terms...."); United States v. Martinez-Fuerte, 428 U.S. 543, 561 (1976) ("[T] ordinarily afforded the most stringent Fourth Amendment protection.").

39. See Payton, 445 U.S. at 576; Welsh v. Wisconsin, 466 U.S. 740, 748-49 (1984). 
remote thermal imaging. ${ }^{40}$ Nor may the state ordinarily enter the home in the absence of a warrant or its equivalent ${ }^{41}$ to assure compliance with civil law obligations such as housing, fire, or related public-safety regulations. ${ }^{42}$ Other constitutional protections, such as the right of free expression, apply with special force as well:

Whatever may be the justifications for other statutes regulating obscenity, we do not think they reach into the privacy of one's own home. If the First Amendment means anything, it means that a State has no business telling a man, sitting alone in his own house, what books he may read or what films he may watch. ${ }^{43}$

Conversely, the First Amendment provides diminished protection to speakers in public forums who direct their speech toward private residences. ${ }^{44}$ As the Supreme Court noted in Frisby v. Schultz,

a special benefit of the privacy all citizens enjoy within their own walls, which the State may legislate to protect, is an ability to avoid intrusions. Thus, we have repeatedly held that individuals are not required to welcome unwanted speech into their own homes and that the government may protect this freedom. ${ }^{45}$

These authorities intuitively recognize that domestic privacy promotes interests that are foundational to a free and secure society. Jerome Frank observed fifty years ago that " $[\mathrm{a}]$ sane, decent, civilized society must provide some . . . oasis, some shelter from public scrutiny, some insulated enclosure, some enclave, some inviolate place which is a man's castle." ${ }^{46}$ As Colb explains,

For a person to be able to enjoy the exercise of her right to marry, to use birth control, and to make parental decisions regarding her children's upbringing and education, she must have a physically private space-a zone in which the government may not acquire personal knowledge of her intimate life. ${ }^{47}$

Empirical research and theoretical literature from the field of psychology corroborate that the "oasis" of the home serves several highly significant emotional and social functions that are crucial to psychological well-being. ${ }^{48}$ Separation from the home, or unwanted intrusions upon it, pose serious psychological risks. ${ }^{49}$ In particular, by

40. Kyllo, 533 U.S. at 40.

41. Marshall v. Barlow's, Inc., 436 U.S. 307, 325 (1978).

42. See id. at 312-13; Camara v. Mun. Court, 387 U.S. 523, 528-29 (1967) (search of home); see also The Supreme Court, 1970 Term-Warrantless Home Visits to Welfare Recipients, 85 HARV. L. REv. 258, 262 (1971) [hereinafter Warrantless Home Visits].

43. Stanley v. Georgia, 394 U.S. 557, 565 (1969).

44. Frisby v. Schultz, 487 U.S. 474, 484-88 (1988); see, e.g., Cohen v. California, 403 U.S. 15, 21 (1971); Rowan v. U.S. Post Office Dep't, 397 U.S. 728, 737 (1970).

45. 487 U.S. at $484-85$.

46. United States v. On Lee, 193 F.2d 306, 315-16 (2d Cir. 1951) (Frank, J., dissenting).

47. Sherry F. Colb, The Qualitative Dimension of Fourth Amendment "Reasonableness," 98 CoLuM. L. REV. 1642, 1705 (1998).

48. See Barros, supra note 5, at 276-80.

49. Id. at $279 \mathrm{n} .110$. 
creating secure space for the existence and development of the family, the home is inextricably linked to the most important and highly protected social institution in our culture. $^{50}$

\section{B. The Homes of the Poor: A Competing Narrative}

The home and the family it shelters are sacrosanct in the rhetoric of our legal tradition, but the historical application of domestic privacy principles has sharply differentiated on grounds of class, race, and gender. ${ }^{51}$ In contrast to the overarching commitment to the security of home and family celebrated by our legal and political culture, the American poor have faced centuries of threats to familial integrity and domestic privacy. While the historical intrusions upon the privacy of the poor are well addressed elsewhere, ${ }^{52}$ a brief review of the indigent's historically insecure claim to home and family provides important context for the contemporary developments discussed in Part II.

\section{Paupers and the Poor Laws}

Poverty was a prominent characteristic of the early American economy, ${ }^{53}$ and colonial America did not view its poor charitably. Then, as in the centuries to follow, public opinion regarding the indigent turned largely on the enduring notion that poverty among the able-bodied is a personal failing reflecting sloth, indolence, or some related moral deficit. ${ }^{54}$ The premise, traceable to the English Poor Laws of the sixteenth and seventeenth centuries, found particularly strong expression in the American colonies where laws regulating the poor "were molded by the religious belief that economic status was a reflection of moral worth." 55 Labeling the able-bodied poor

50. See, e.g., Gregory v. City of Chicago, 394 U.S. 111, 125 (1969) (Black, J., concurring) (stating that the home is "the sacred retreat to which families repair for their privacy and their daily way of living"); Barros, supra note 5, at 272; Robin Morris Collin \& Robert William Collin, Are the Poor Entitled to Privacy?, 8 HARV. BLACKLETTER L.J. 181, 191 (1991).

51. See Hafetz, supra note 3, at 240; William P. Quigley, The Quicksands of the Poor Law: Poor Relief Legislation in a Growing Nation 1790-1820, 18 N. ILL. U. L. REv. 1, 88-93 (1997) [hereinafter Quigley, Quicksands] (discussing race discrimination).

52. See, e.g., GllLIOM, supra note 1; MichaEL B. KATZ, IN THE SHADOW OF THE POORHOUSE: A SOCIAL HISTORY OF WELFARE IN AMERICA (1986); Hafetz, supra note 3.

53. See Burkhart, supra note 2, at 227 (recounting that up to $20 \%$ of the white population at the time of the American Revolution lived in poverty while an additional $20 \%$ of the total population was enslaved); $i d$. at 217 (noting that England viewed America as "a dumping ground for its most economically burdensome residents-criminals and the poor"); see also William P. Quigley, Work or Starve: Regulation of the Poor in Colonial America, 31 U.S.F. L. REV. 35, 71-78 (1996) [hereinafter Quigley, Work or Starve].

54. See, e.g., William P. Quigley, Backwards into the Future: How Welfare Changes in the Millennium Resemble English Poor Law of the Middle Ages, 9 STAN. L. \& POL'Y REV. 101, 105-06 (1998) [hereinafter Quigley, Backwards]; Quigley, Reluctant Charity, supra note 2, at 114; Thomas Ross, The Rhetoric of Poverty: Their Immorality, Our Helplessness, 79 Geo. L. J. $1499,1502-08$ (1991).

55. Burkhart, supra note 2, at 221-22; see also Quigley, Reluctant Charity, supra note 2, at 114 ("The themes of English poor law that continued to resonate in the earliest American poor 
as "paupers," religious leaders offered Americans a theological indictment of their condition: "Pauperism," lectured one, "is the consequence of wilful error, of shameful indolence, of vicious habits. It is a misery of human creation, the pernicious work of man, the lamentable consequence of bad principles and morals." 56 Prominent Founders endorsed the view: John Adams wrote that "very few men who have no property have any judgment of their own," "while Benjamin Franklin argued against "encouragement for laziness, and supports for folly" on grounds that "the order of God and Nature . . perhaps has appointed want and misery as the proper punishments for, and cautions against, as well as necessary consequences of, idleness and extravagance." 58 In 1837, the United States Supreme Court forthrightly embraced the sentiment in a decision upholding a statute requiring passengers on arriving ships to report their occupation:

We think it as competent and as necessary for a state to provide precautionary . measures against the moral pestilence of paupers ... as it is to guard against the physical pestilence, which may arise from ... a ship, the crew of which may be laboring under an infectious disease.

Reduced to the status of moral pestilence, the poor were broadly excluded from economic and political rights in colonial America and the early United States. The Articles of Confederation specifically excluded "paupers, vagabonds, and fugitives from justice" from the privileges and immunities of citizenship. ${ }^{60}$ Those in need of public assistance "could be jailed, sold at auction, or indentured at the discretion of... individual towns or communities." Settlement laws barred the poor from moving to new communities and empowered local officials to detain and return them to their prior residences. ${ }^{62}$ Begging, indebtedness, and the failure to become self-supporting were crimes punishable by imprisonment or public whipping. ${ }^{63}$ Indentured servitude persisted from the colonial era into the nineteenth century, ${ }^{64}$ with two-thirds of immigrants to some states in the late eighteenth and early nineteenth centuries arriving as indentured laborers with vastly diminished legal and political rights. ${ }^{65}$ As late as the early twentieth century, several states continued to deny paupers-typically defined to include anyone receiving public assistance-the right to vote or hold public office. ${ }^{66}$

laws include [the treatment of poverty] not as an economic problem, but as an individual failure ....").

56. Ross, supra note 54, at 1505 (quoting Reverend Charles Burroughs, A Discourse Delivered in the Chapel of the New Alms-House in Portsmouth, New Hampshire (1835)).

57. Burkhart, supra note 2, at 214 (quoting Letter from John Adams to James Sullivan (May 26, 1776), in 9 THE Works OF JoHn ADAMS at 367-77 (C. Adams ed., 1864)).

58. Letter from Benjamin Franklin to Richard Jackson (May 5, 1753), in 3 THE WRITINGS OF BENJAMIN FRANKLIN 135 (Albert Henry Smyth ed., 1905).

59. City of New York v. Miln, 36 U.S. (11 Pet.) 102, 142-43 (1837).

60. ARTICLES OF CONFEDERATION art. 4, $\S 1$; see also Quigley, Reluctant Charity, supra note 2 , at 176 .

61. Quigley, Reluctant Charity, supra note 2, at 160.

62. See id. at 140-50; Quigley, Quicksands, supra note 51, at 78-84.

63. See Quigley, Reluctant Charity, supra note 2, at 160-69.

64. Burkhart, supra note 2, at 221.

65. See id. at 220-21; Quigley, Quicksands, supra note 51, at 87; Quigley, Work or Starve, supra note 53, at 71-76.

66. Burkhart, supra note 2, at 256; Quigley, Quicksands, supra note 51, at 93-94. 
Against this backdrop of social condemnation and formal oppression, the growing ranks of the poor in the early United States faced grave threats to domestic privacy and familial security. ${ }^{67}$ Proceeding from the premise that poverty-absent some extenuating condition-was the fault of those who suffered it, early English and American poor laws distinguished between the "deserving" (i.e., the physically or mentally infirm) and the "undeserving" (i.e., the able-bodied) and typically excluded the latter from aid. ${ }^{68}$ Able-bodied poor instead were expected to support themselves and, if they failed to do so, faced harsh consequences including commitment to a "workhouse," "house of correction," or debtor's prison. ${ }^{69}$ Following a parent's incarceration as a debtor or pauper, the poor family often disintegrated: "Even a debtor's children could be sold to pay the creditor."70

While the state offered aid rather than punishment to the "deserving" poor, its assistance nonetheless reflected the shameful status of indigency and a belief that any relief might create an unhealthy dependence upon it. ${ }^{71}$ Early poor laws thus were designed to provide aid in a manner sufficiently unattractive to incentivize the needy to seek it only in true desperation-often at the cost of home and family. ${ }^{72}$ As in England, the American poor during the seventeenth, eighteenth, and nineteenth centuries faced periodic demands that they abandon their dwellings and move to "poorhouses" or "almshouses" in exchange for meager public relief. ${ }^{73}$ As an alternative to the poorhouse, communities in the eighteenth and early nineteenth centuries commonly removed the needy from their homes and placed them with private families who received public funds to provide basic care and shelter in return for work. ${ }^{74}$ The process often operated in a particularly humiliating fashion: in many localities, the poor were literally auctioned off to the homeowners who submitted the lowest bids for their care. $^{75}$

67. William P. Quigley, Five Hundred Years of English Poor Laws, 1349-1834: Regulating the Working and Nonworking Poor, 30 AKRON L. REV. 73, 126-27 (1996) [hereinafter Quigley, Five Hundred Years].

68. See, e.g., Quigley, Work or Starve, supra note 53, at 35, 42-45; Ross, supra note 54, at 1502-08; see also HERBERT J. GANS, THE WAR AGAINST THE POOR 74-102 (1995) (discussing contemporary application of principle); GILLIOM, supra note 1, at 22. Notably, early poor laws typically stipulated that "deserving" recipients of aid must be white. Quigley, Quicksands, supra note 51 , at 54 .

69. Burkhart, supra note 2, at 222-23; Quigley, Reluctant Charity, supra note 2, at 160-69; Quigley, Work or Starve, supra note 53, at 62-63.

70. Burkhart, supra note 2, at 223.

71. Quigley, Five Hundred Years, supra note 67, at 127.

72. Id. at 110; see also Eric A. Posner, Contract Law in the Welfare State: A Defense of the Unconscionability Doctrine, Usury Laws, and Related Limitations on the Freedom of Contract, 24 J. LEGAL STUD. 283, 310 (1995); Quigley, Backwards, supra note 54, at 104-05; Quigley, Reluctant Charity, supra note 2, at 114.

73. See Quigley, Quicksands, supra note 51, at 73-78; Quigley, Reluctant Charity, supra note 2, at 156-60; William F. Quigley, Rumblings of Reform: Northern Poor Relief Legislation in Antebellum America, 1820-1860, 26 CAP. U. L. REV. 739, 768 (1997) [hereinafter Quigley, Rumblings]; Quigley, Work or Starve, supra note 53, at 61-63.

74. See Quigley, Quicksands, supra note 51, at 69-73; Quigley, Rumblings, supra note 73, at 756-57; Quigley, Work or Starve, supra note 53, at 61-62.

75. Burkhart, supra note 2, at 223-24. 


\section{Unfit Homes and Friendly Visitors}

Following the Civil War, "[u]rbanization, industrialization, and mass immigration transformed the nation's landscape, sparking fears its homes and families were being undermined and endangering the entire social order." perils, social reformers launched "countless experiments . . . in the nation's programs for the poor" ${ }^{77}$ involving "extensive intervention into the homes and private lives of [aid] recipients." ${ }^{78}$ Child protection was an important focus of this interventionist zeal, prompting aggressive efforts by public officials to remove children from "unfit homes" for placement with foster families or orphanages. ${ }^{79}$ As with the poor laws of previous centuries, these new efforts rested on a belief that poor and immigrant parents "lack[ed] ... the cardinal virtues of 'will, work ethic, thrift, responsibility, and honesty" ${ }^{80}$ and thus must be separated from their children to thwart the corrupting influence. $^{81}$ To accomplish this objective, the state and allied private charities conducted "sweeping investigations of private homes that were fundamentally at odds with the judicial exaltations of the home's sanctity in other settings," including such practices as warrantless home searches, late-night and early-morning raids, and entry through windows. ${ }^{82}$

In the early decades of the twentieth century, under the growing influence of progressive reformers, the focus of child protection policies shifted from removal and institutionalization to the provision of care within the home. ${ }^{83}$ This shift in focus, however, did not result in any greater deference to the domestic privacy of the poor. Instead, agents of the state continued to enter homes and search premises freely-now to assess the needs of children and to closely supervise the provision of assistance to their families. ${ }^{84}$

The Progressive Era of the early twentieth century gave rise to another important development in the provision of indigent assistance: the Mothers' Pensions, which laid much of the groundwork for modern welfare administration. ${ }^{85}$ These programs, designed to provide single mothers with closely supervised financial assistance, incorporated the premise that the state should limit relief to the "deserving" poor based on "[m]oralistic considerations, such as whether the recipient's children were legitimate." ${ }^{86}$ To determine recipients' worthiness and to assure that the poor properly

76. Hafetz, supra note 3, at 203.

77. GLLIOM, supra note 1, at 24; see also Hafetz, supra note 3, at 178.

78. Hafetz, supra note 3, at 178, 204-24.

79. See id. at 205-12.

80. Id. at 209 (quoting LINDA GoRdON, HeROES OF THEIR OWN LIVEs: THE POLITICS AND HISTORY OF FAMILY VIOLENCE, BOSTON 1880-1960, at 62 (1988)); see also KATZ, supra note 52 , at 108.

81. Hafetz, supra note 3, at 207-08.

82. Id. at 208.

83. Id. at 213-14; Mark H. Leff, Consensus for Reform: The Mothers' Pension Movement in the Progressive Era, 47 SOC. SERV. REV. 397, 410 (1973).

84. Hafetz, supra note 3, at 214.

85. GLLIOM, supra note 1 , at 25 .

86. Hafetz, supra note 3, at 217; see also Tonya L. Brito, From Madonna to Proletariat: Constructing a New Ideology of Motherhood in Welfare Discourse, 44 VILL. L. REV. 415, 420 
used their aid, Mothers' Pensions relied on an administrative method that continues to characterize contemporary welfare relief: "the 'friendly visitor,' a prototype of the modern social worker who would go into the homes of the poor to advise, inspect, support, and instruct." ${ }^{1,7}$ Among the primary tasks of the friendly visitor was to assure that poor mothers maintained "suitable homes," a highly subjective norm that empowered the state to inquire into virtually all aspects of a recipient's private life. ${ }^{88}$ To assure the maintenance of suitable-home standards, visiting officials conducted "midnight raids in search of male visitors," prohibited evening dates. 90

With the onset of the Depression, as the federal government began to assume responsibility for much of the poverty relief formerly provided by the Mothers' Pensions, it carried forward the administrative concepts of the friendly visitor and suitable home. 91 As Gordon notes, "Home visits were the norm in casework at this time $\ldots[\mathrm{T}]$ he assumption remained that a public assistance client was in need of counseling and rehabilitation and had fewer privacy rights than others." ${ }^{, 92}$ For example, in the decades following the Depression, many localities administering federal programs imposed "man-in-the-house" prohibitions that empowered case workers to make unannounced home visits in search of male companions. ${ }^{93}$

As government subsidies, grants, and financial aid to other groups and individuals proliferated during the twentieth century, the longstanding premise that the poor sacrificed their right of privacy in exchange for public assistance stood in increasing tension with the undiminished rights of others receiving government largesse. ${ }^{94}$ Inevitably, the continuing use of home visits, late-night raids, and related surveillance techniques through the $1950 \mathrm{~s}$ and $1960 \mathrm{~s}^{95}$ collided with the Fourth Amendment as activists in the nascent welfare-rights movement sought to extend increasingly robust protections against warrantless home searches ${ }^{96}$ to welfare recipients. ${ }^{97}$ In Wyman $v$.

(1999).

87. GLLloM, supra note 1, at 24; see Hafetz, supra note 3, at 220 ("[A]dministering officials . . . considered regular home visits indispensible.").

88. Gilliom, supra note 1, at 25; Hafetz, supra note 3, at 221.

89. GILLIOM, supra note 1 , at 25 .

90. Hafetz, supra note 3, at 222-23.

91. See Linda Gordon, Pitied but not ENTTTLED: Single Mothers AND THe History of WeLFARE, 1890-1935, at 1-13, 37, 275-76 (1994); Brito, supra note 86, at 423; Betsy Ledbetter Hancock \& Leroy H. Pelton, Home Visits: History and Function, 70 J. CONTEMP. Soc. WORK 21 (1989).

92. GORDON, supra note 91, at 296; see GILLIOM, supra note 1, at 26 ("It was here, in the program for women and children, that the most degrading and invasive tactics of modern welfare would be seen.").

93. Brito, supra note 86, at 423; Hafetz, supra note 3, at 224-25; see also GILlIOM, supra note 1 , at 27.

94. See, e.g., Wyman v. James, 400 U.S. 309, 326-28 (1971) (Douglas, J., dissenting); J. Skelly Wright, Poverty, Minorities, and Respect for Law, 1970 DUKE L.J. 425, 438.

95. GLLIOM, supra note 1, at 31-32 ("Until the late 1960s, AFDC administrators in some areas of the country had undertaken midnight or early-morning raids to see if an unreported male was present in an allegedly single-parent home.").

96. See, e.g., Camara v. Mun. Court, 387 U.S. 523 (1967).

97. Hafetz, supra note 3, at 226-27. 
James, ${ }^{98}$ the Supreme Court addressed the question and confirmed that the rhetoric of domestic sanctity stopped at the doorstep of the indigent.

\title{
C. Wyman v. James: Resolving the Conflict in Favor of the State
}

The Supreme Court's 1971 decision in Wyman considered whether public officials could condition welfare benefits upon the recipients' consent to periodic home visits by caseworkers. ${ }^{99}$ The Court began its discussion of the question by acknowledging the home's special status in Fourth Amendment jurisprudence:

\begin{abstract}
When a case involves a home and some type of official intrusion into that home, as this case appears to do, an immediate and natural reaction is one of concern about Fourth Amendment rights and the protection which that Amendment is intended to afford. Its emphasis indeed is upon one of the most precious aspects of personal security in the home.... And over the years the Court consistently has been most protective of the privacy of the dwelling. ${ }^{100}$
\end{abstract}

Having acknowledged "[t]his natural and quite proper protective attitude," the Court immediately declared that it was irrelevant to the case--"for the seemingly obvious and simple reason that we are not concerned here with any search ... in the Fourth Amendment meaning of that term." ${ }^{101}$ In a cursory passage, the Court asserted that home visits fell outside the scope of the Fourth Amendment because of the predominantly rehabilitative (as opposed to investigative) purpose of the caseworker's visit and the fact that a visit, if any, occurred only by consent. ${ }^{102}$ These rationales attracted considerable criticism. ${ }^{103}$ First, the Court itself had previously defined a Fourth Amendment search in far more inclusive terms that captured virtually any intrusion by state agents upon personal privacy ${ }^{104}$-a standard that surely reached the entry at issue in Wyman. ${ }^{105}$ Second, the Court's focus on the rehabilitative purpose of the visit conflicted with settled precedent establishing that the objective of the state's intrusion, and the civil or criminal consequences (if any) that follow, are irrelevant to the initial determination of whether the entry falls within the ambit of Fourth Amendment scrutiny. ${ }^{106}$ Finally, the Court's discussion of consent made no sense: free

98. 400 U.S. $309(1971)$.
99. Id. at 310.
100. Id. at 316.
101. Id. at 317.
102. Id. at $317-18$.
103. See Robert A. Burt, Forcing Protection on Children and Their Parents: The Impact of Wyman v. James, 69 MiCH. L. REV. 1259, 1302-03 (1971); Warrantless Home Visits, supra note 42, at 259-61; see also 5 WAYNe R. LAFAVE, SEARCH \& SEIZURE: A TrEatise ON THE FOURTH AMENDMENT $§ 10.3$ (a) (4th ed. 2004) ("[T] Court is unquestionably incorrect in its assertion that a home visit is not a search."); Ginny Kim, Note, Unconstitutional Conditions: Is the Fourth Amendment for Sale in Public Housing?, 33 AM. CRIM. L. REV. 165, 180-84 (1995).

104. See, e.g., Terry v. Ohio, 392 U.S. 1,18 n.15 (1968).

105. Warrantless Home Visits, supra note 42, at 260 (stating that the nature of the entries at issue in Wyman "provide[s] strong support for viewing the home visits as searches within the Court's previous definition").

106. See, e.g., California v. Ciraolo, 476 U.S. 207, 226 (1986) (Powell, J., dissenting); 
and voluntary consent serves to validate-not eliminate-a Fourth Amendment search. $^{107}$

As an alternative ground, the Court held that the visit, even if construed as a search under the Fourth Amendment, was reasonable and thus permissible based on the balance of relevant interests. ${ }^{108}$ Since the visit at issue involved neither a warrant nor any individualized suspicion of wrongdoing, the Court's ruling in this respect withheld from welfare recipients virtually all of the procedural and substantive protections available under the Fourth Amendment. ${ }^{109}$ In support of its conclusion, the Court recited an "ad hoc" misconstrued precedent, ${ }^{11}$ trivialized the intrusive and often adversarial nature of the caseworker's presence within the home, ${ }^{112}$ and stigmatized poor parents based on archaic stereotypes. ${ }^{113}$

The Court's reasonableness analysis placed significant emphasis on the fact that no criminal sanctions attended the refusal to authorize a home visit-instead, aid simply ceased. ${ }^{114}$ The Court asserted that this consideration distinguished the case from earlier and more protective decisions involving civil searches, such as Camara v. Municipal Court ${ }^{115}$ and See v. City of Seattle, ${ }^{116}$ in which criminal sanctions might have resulted

Camara v. Mun. Court, 387 U.S. 523, 530-31 (1967).

107. Cf. Schneckloth v. Bustamonte, 412 U.S. 218, 222 (1973) (affirming that "a search conducted pursuant to a valid consent is constitutionally permissible"). The Wyman Court did not discuss consent in the portion of its analysis that assumed, arguendo, that the proposed home visits would constitute a search-presumably because Mrs. James had refused entry and therefore rendered the defense irrelevant in her particular case. The question remains, however, whether recipients who do consent to home visits on the terms at issue would effectively waive their Fourth Amendment rights. The question turns on whether such consent is free and voluntary. Schneckloth, 412 U.S. at 227; Camara, 387 U.S. at 528. Considering the consequences faced by a recipient who withholds consent, the context is powerfully coercive: "What greater inhibition to freedom can there be than that which a welfare recipient faces when subjected to a threat by the authorities to eliminate her sole means of providing food, shelter and clothing for her family? This is coercion in its purest form." Reyes v. Edmunds, $472 \mathrm{~F}$. Supp. 1218,1226 (D. Minn. 1979); $c f$. Wyman, 400 U.S. at 341 (Marshall, J., dissenting) (noting that a recipient who withholds consent terminates "the sole means of support" for herself and her children); see also infra, note 257.

108. Wyman, 400 U.S. at 318-26.

109. Id. at 326; see 5 LAFAVE, supra note $103, \S 10.3$ (a) (noting that a warrant requirement in this context would "afford[] some protection against arbitrary searches and does not "leave the occupant subject to the discretion of the official in the field" (quoting Camara, 387 U.S. at 532)); Colb, supra note 47, at 1718-19.

110. Wyman, 400 U.S. at 341 (Marshall, J., dissenting) ("[I]n determining whether a search is reasonable, this Court is not free merely to balance, in a totally ad hoc fashion, any number of subjective factors."); see Warrantless Home Visits, supra note 42, at 262 ("[F]ailing to attach any weight to the factors... will leave lower courts in a quandary when they attempt to decide whether other noncriminal intrusions into the home require prior resort to the warrant.").

111. See, e.g., 5 LAFAVE, supra note 103, $\S 10.3$ (a) (observing that the Court's argument against the warrant requirement "is difficult to take . . . seriously" in view of prior precedent).

112. Colb, supra note 47 , at $1720-22$.

113. Ross, supra note 54 , at 1523-25.

114. Wyman, 400 U.S. at 321, 323-25.

115. 387 U.S. 523 (1967).

116. 387 U.S. 541 (1967). 
from the refusal to permit an administrative home inspection. ${ }^{117}$ The argument, however, turned those decisions on their head. The entire thrust of Camara and See was to discard the civil-criminal distinction for purposes of assessing the applicability of the Fourth Amendment warrant requirement and to overrule prior authorityspecifically, Frank v. Maryland ${ }^{18}$ - to the contrary. ${ }^{119}$ LaFave thus observes that the Wyman Court's argument rested on "[p]recisely the unsound premise of the earlier Frank case which was rejected by the Court in Camara." ${ }^{120}$ Yet even if the distinction were relevant, Justice Marshall explained in dissent that it provided little support for the majority's conclusion in Wyman:

Even if the magnitude of the penalty were relevant, which sanction for resisting the search is more severe? For protecting the privacy of her home, Mrs. James lost the sole means of support for herself and her infant son. For protecting the privacy of his commercial warehouse, Mr. See received a $\$ 100$ suspended fine. ${ }^{121}$

The Court also asserted that the state's interest in assuring the fiscal integrity of the public assistance program supported the reasonableness of the challenged searches. ${ }^{122}$ Noting that "tax funds provided from federal as well as from state sources" supported the relief at issue, the Court recognized a "paramount interest and concern in seeing and assuring that the intended and proper objects of that tax-produced assistance are the ones who benefit from the aid it dispenses." 23 "The public," the Court opined, "[rightly] expects to know how [its] charitable funds are utilized and put to work."124 The reach of this argument obviously extends much further than the Court acknowledged, since the state has precisely the same interest in the fiscal integrity and administration of virtually any subsidy, grant, tax credit, deduction, or other form of public aid. If the recipients of such aid-truly, nearly every person in the countrywere understood to have sacrificed their Fourth Amendment rights to the extent required for the government to assure that the aid in question benefited only the "intended and proper objects of that tax-produced assistance," 125 "the cries of constitutional outrage would be unanimous." 126 The Court evidently sought to avert such a construction by restricting its analysis to public "charity,"127 a term that merely isolates a particular class of aid recipients-the poor-for the special burdens that the Court imposed.

117. Wyman, 400 U.S. at 324-25.

118. 359 U.S. 360 (1959), overruled by Camara, 387 U.S. 523.

119. Camara, 387 U.S. at 530; see, e.g., Marshall v. Barlow's, Inc., 436 U.S. 307, 312-13

(1978) ("[T]he Fourth Amendment prohibition against unreasonable searches protects against warrantless intrusions during civil as well as criminal investigations.").

120. 2 Wayne R. LaFave, Jerold H. Israel, Nancy J. King \& OrIn S. Kerr, Criminal Procedure § 3.9(d), at 364 n.63 (3d ed. 2007).

121. Wyman, 400 U.S. at 341 (Marshall, J., dissenting).

122. Id. at 318-19.

123. Id.

124. Id. at 319 .

125. Id.

126. Id. at 343 (Marshall, J., dissenting).

127. Id. at 319 . 
Another factor heavily relied upon by the Wyman Court was the caseworker's purportedly trusting and supportive relationship with the recipient and the unobtrusive nature of the home entry itself. Evoking the mythic "friendly visitor" of the nineteenth century, ${ }^{128}$ the Court declared that the caseworker was not an adversarial "sleuth but rather, we trust, ... a friend to one in need."129 The decision repeatedly returned to the "rehabilitative" and "personal" nature of the visit, coupled with the absence of "forcible entry or entry under false pretenses or visitation outside working hours or snooping in the home," 130 and on that basis asserted that the intrusive dimension of the search was trivial. ${ }^{131}$ This analysis notably omitted two central considerations: first, that the "friendly" visit was an involuntary entry into the home of the aid recipient- the paramount zone of privacy that, in other contexts, the Court had repeatedly acknowledged to be sacrosanct; ${ }^{132}$ and, second, that the presence of a caseworker was inherently intrusive and disruptive of the family's autonomy, irrespective of the absence of any "impolite or reprehensible conduct." social worker does not participate in rearing the child, he might be unable to gauge when it is or is not appropriate to interfere with what the mother has chosen to do. As the mother's judge, rather than her colleague, his very presence is likely to undermine the mother's authority in her home." 134 Notably, the Court's effort in this regard to depict the visits as "personal" and "rehabilitative" conspicuously ignored that the caseworker was required to initiate a criminal investigation if anything observed within the home raised suspicions of fraud. ${ }^{135}$

Completing the Court's reasonableness analysis was a factor squarely at odds with the preceding proposition. In emphasizing the state's "paramount" interest in entering the home, the Court shifted away from the conception of a gentle and helpful caseworker to the need for investigative scrutiny of the residence to assure the protection of the children within. ${ }^{136}$ Here the Court turned its attention to adult recipients and rendered a depiction of them in the long tradition of the morally bereft poor. ${ }^{137}$ Indigent children, we are told, require protection from "possible exploitation" 138 at the hands of their avaricious parents, who otherwise might divert aid to satisfy their own desires:

The public's interest in this particular segment of the area of assistance to the unfortunate is protection and aid for the dependent child whose family requires

128. See supra notes $87-90$ and accompanying text.

129. Wyman, 400 U.S. at 323.

130. Id. at 321 .

131. See id. at $317,319-21$.

132. See supra notes 34-38 and accompanying text; see also Coleman, supra note 37, at 506.

133. Wyman, 400 U.S. at 321.

134. Colb, supra note 47, at 1721; accord, Cahn, supra note 3, at 1242-43. The record in Wyman itself belied the image of a benevolent caseworker who entered without adversarial intent to assist the recipient. Wyman, 400 U.S. at 339-40 (Marshall, J., dissenting).

135. Wyman, 400 U.S. at 339-40 (Marshall, J., dissenting).

136. Id. at 318-19; see id. at 344 (Marshall, J., dissenting) ("Throughout its opinion, the majority alternates between two views of the State's interest in requiring the home visit.").

137. See supra notes 54-59,80-81 and accompanying text.

138. Wyman, 400 U.S. at 319. 
such aid for that child. The focus is on the child and, further, it is on the child who is dependent. . . . The dependent child's needs are paramount, and only with hesitancy would we relegate those needs, in the scale of comparative values, to a position secondary to what the mother claims as her rights. ${ }^{139}$

Ross concludes that the Court thus "placed the state and the child in opposition to the mother," an alignment that "depends on the assumption of a propensity of the mother to act contrary to the interests of her children."140

To corroborate this asserted need for investigative scrutiny, the Court turned to Mrs. James herself-despite the fact that the case involved a challenge to the defendant's general search practices, which operated without suspicion of or regard for the plaintiff's particular conduct - and suggested that she was precisely the kind of abusive and immoral parent who demonstrated the need to intrude upon the homes of the poor. "We have examined Mrs. James' case record," the Court observed, and

[it] is revealing as to [her] failure ever really to satisfy the requirements for eligibility; as to constant and repeated demands; as to attitude toward the caseworker; as to reluctance to cooperate; as to evasiveness; and as to occasional belligerency. There are indications that all was not always well with the infant Maurice... The picture is a sad and unhappy one. ${ }^{141}$

The Court's premise of the immoral poor, now corroborated and embodied by an anecdotal caricature of Mrs. James herself, supplied the state with the necessary interest to exempt all indigent parents from otherwise applicable constitutional protections. "The story of Mrs. James and the infant Maurice becomes a story of all AFDC mothers and their propensity, by virtue of their poverty, to abuse their children." ${ }^{.142}$ By imputing to impoverished parents this universal risk of misconduct, Wyman implicitly transformed the suspicionless home searches at issue into the sort of cause-based investigative entries traditionally associated with the protections of the Fourth Amendment. Supplanting the need for individualized suspicion, the recurring premise of the immoral poor opened the doors of Mrs. James's home for the protection of her child.

139. Id. at 318 (emphasis omitted).

140. Ross, supra note 54, at 1523-24; see also Wyman, 400 U.S. at 342 (Marshall, J., dissenting) ("[I]s this Court prepared to hold as a matter of constitutional law that a mother, merely because she is poor, is substantially more likely to injure or exploit her children?"); Colb, supra note 47 , at 1716 .

141. Wyman, 400 U.S. at 322 n.9. Of course, this account uncritically credits the objectivity of the reporting caseworker. Here, as elsewhere, there are likely two sides to the story. The agency's characterization of Mrs. James as "reluctan[t] to cooperate," "evasive[]," and "occasional[ly] belligeren[t]," id., could alternatively reflect her legitimate if unwelcome resistance to its exercise of arbitrary authority. In any event, the record was amenable to a quite different construction: "The record shows that Mrs. James has offered to be interviewed anywhere other than her home, to answer any questions, and to provide any documentation that the welfare agency desires. The agency curtly refused all these offers and insisted on its 'right' to pry into appellee's home." Id. at 343 (Marshall, J., dissenting).

142. Ross, supra note 54 , at 1525. 
Wyman's enumerated factors-the noncriminal nature of the visit, the state's interest in fiscal integrity, the helpful attitude of the caseworker, and the posited threat to the welfare of all poor children-offered virtually no doctrinal support for the conclusion that the visits at issue constituted either no search at all or, alternatively, a permissible entry in the absence of a warrant or suspicion. The very weakness of the formal analysis raises the question whether the Court was engaged in a fundamentally different sort of discourse. Much of the opinion reads less like constitutional adjudication than a parental lecture: a benevolent patriarch imposes upon a wayward child "a gentle means, of limited extent and of practical and considerate application," to assure that she properly spends an allowance. ${ }^{143}$ The implicit message is that the poor stand apart for purposes of rights enforcement. By virtue of their moral infirmity, coupled with their indebtedness to the state for its support, the indigent approach the Court not as litigants but as supplicants in hopes of dispensation. The task is not to determine constitutional entitlement but rather to judge a plea for indulgence, which the Court in Wyman deemed unworthy.

\section{Abandoning Pretense: The Contemporary ApPlication of WyMan}

As an affirmation of longstanding bias and an implicit declaration that the poor are simply different for purposes of constitutional analysis, Wyman challenged the lower courts to define its reach. Should the ruling herald a new era of retrenchment in the poor's struggle for equal justice, or should it instead be cast as an outlier-a decision so poorly reasoned and at odds with allied precedent that its holding must be limited to the narrowest plausible construction?

In the 1970s and 1980s, a handful of lower courts embraced the latter view. ${ }^{144}$ Asserting that the Wyman Court "emphasized the peculiar factual situation of the case" and noting the inconsistency of its reasoning with other Fourth Amendment precedents, the D.C. Circuit concluded in 1975 that the Supreme Court had "limited Wyman to its particular factual context." 145 In 1979, a district court declined to apply Wyman to search practices utilized by a mobile unit of caseworkers who visited the homes of recipients accused of welfare fraud. ${ }^{146}$ The court noted that " $[t]$ he majority opinion in Wyman v. James is not without conceptual problems, and, in view of the vigorous, persuasive three-judge dissenting opinions, the holding must be restricted to the boundaries imposed by the facts to avoid glaring inconsistency with prior search and seizure cases." "147 Another district court echoed the conclusion in a 1988 decision

143. Wyman, 400 U.S. at 319; see also id. at 321-22 ("What Mrs. James appears to want from the agency that provides her and her infant son with the necessities for life is the right to receive those necessities upon her own informational terms, to utilize the Fourth Amendment as a wedge for imposing those terms, and to avoid questions of any kind.").

144. See Zweibon v. Mitchell, 516 F.2d 594, 632 n.94 (D.C. Cir. 1975); Blackwelder v. Safnauer, 689 F. Supp. 106, 140-41 (N.D.N.Y. 1988); Reyes v. Edmunds, 472 F. Supp. 1218, 1224 (D. Minn. 1979); $c f$. Walsh v. Erie County Dep't of Job and Family Servs., 240 F. Supp. 2d. 731,746 (N.D. Ohio 2003).

145. Zweibon, 516 F.2d at 633 n.94.

146. Reyes, 472 F. Supp. at 1224.

147. Id. 
declining to extend Wyman to on-site observations of homeschooled students. ${ }^{148}$ Noting that the inspections under review were "analogous" to several key features of the Wyman visits, the court nonetheless concluded that Wyman "seems inconsistent with prevailing fourth amendment analysis, and the precedential effect of Wyman probably should be limited to the specific facts of that case."149

Other courts, while not expressing doubt regarding the force of the precedent, have declined to extend it in related areas. ${ }^{150}$ The topic most frequently addressed in this context has been the permissibility of warrantless search practices in child abuse and neglect investigations. ${ }^{151}$ Despite the relationship of Wyman and its rationale to the challenged policies, ${ }^{152}$ most federal courts have declined to uphold the searches-most often because of the potential criminal implications of a child-abuse finding. ${ }^{153}$ As one

148. Blackwelder, 689 F. Supp. at $140-41$.

149. Id. at 140; see also id. at 138 ("Though defendants accurately observe that the sort of home visits contemplated by the school superintendents in the case at bar are similar in a number of relevant respects to the visitations at issue in Wyman, the court declines to follow Wyman's narrow conception of the scope of the fourth amendment, largely because it is inconsistent with the weight of Supreme Court precedent."). But see United States v. Cogwell, 486 F.2d 823, 835-37 (7th Cir. 1973) (applying the Wyman rationale to justify warrantless police visits to job-training centers to investigate possible fraud); $c f$. Lovvorn $\mathrm{v}$. City of Chattanooga, 846 F.2d 1539, 1553-54 (6th Cir. 1988) (Guy, J., dissenting) (citing the Wyman rationale in dissent as justification for suspicionless drug testing), reh'g granted, judgment vacated en banc, 861 F.2d 1388 (6th Cir. 1988) (upholding practice without reference to Wyman).

150. See, e.g., Rosen v. Hursh, 464 F.2d 731, 735 (8th Cir. 1972) (declining to extend Wyman to justify income verification rules); de la O v. Arnold-Williams, No. CV-04-0192-EFS, 2006 WL 3761335, at *4 (E.D. Wash. Dec. 20, 2006) (declining to extend Wyman to searches of in-home day care facilities); Bowser v. Blair County Children and Youth Serv., 346 F. Supp. 2d $788,800-01$ (W.D. Pa. 2004) (declining to extend Wyman to invasion of privacy claim based on presence of third-parties accompanying social worker during home visit).

151. These arguments have relied both on Wyman and on the "special needs" doctrine. Decisions expressly rejecting the applicability of Wyman include: Calabretta v. Floyd, 189 F.3d 808, 816 (9th Cir. 1999); Walsh v. Erie County Department of Job and Family Services, 240 F. Supp. 2d 731, 745-46 (N.D. Ohio 2003); and Lopkoff v. Slater, 898 F. Supp. 767, 773 (D. Colo. 1995), aff'd, 103 F.3d 144 (10th Cir. 1996). Cases reaching the same outcome based on a special-needs analysis include: Good v. Dauphin County Social Services for Children and Youth, 891 F.2d 1087, 1092-96 (3d Cir. 1989); White ex rel. White v. Pierce County, 797 F.2d 812, 815 (9th Cir. 1986); and Franz v. Lytle, 791 F. Supp. 827, 830-31 (D. Kan. 1992), aff'd, 997 F.2d 784 (10th Cir. 1993).

152. Cf. Mark Hardin, Legal Barriers in Child Abuse Investigations: State Powers and Individual Rights, 63 WASH. L. REV. 493, 523 (1988) (noting that Wyman's focus on "the rehabilitative character of welfare home visits and the need to protect dependent children ... may offer some support for a relaxed evidentiary standard governing searches pursuant to child abuse investigations").

153. See supra note 151 ; cf. Hardin, supra note 152 , at 523, 538. But see Wildauer v. Frederick County, 993 F.2d 369, 372 (4th Cir. 1993); Darryl H. v. Coler, 801 F.2d 893, 902 (7th Cir. 1986), aff'g E.Z. v. Coler, 603 F. Supp. 1546, 1555 (N.D. Ill. 1985), and aff'g in part, vacating in part Darryl H. v. Coler, 585 F. Supp. 383, 389-90 (N.D. Ill. 1984). See generally Roe v. Texas Dep't of Protective \& Regulatory Servs., 299 F.3d 395, 403-05 (5th Cir. 2002) (noting circuit split); Coleman, supra note 37, at 471-76 (noting that of the eight circuits to 
district court explained, "To accept the defendants' claims about the reach of Wyman would give the state unfettered and absolute authority to enter private homes and disrupt the tranquility of family life on nothing more than an anonymous rumor that something might be amiss." 154

Judicial reluctance to extend the reach of Wyman has only gone so far, however, and is least evident when the targets of intrusion are exclusively poor. Accordingly, within the classic context of welfare administration, the courts have shown little restraint in embracing and enlarging the precedent. ${ }^{155}$ In considering challenges to new and highly intrusive administrative practices arising out of the welfare-reform movement of the 1980 s and 1990 s, lower courts have not merely conformed to Wyman's analysis but aggressively extended its reasoning beyond the scope of the original ruling -consigning aid applicants to unannounced and exhaustive searches of their bedrooms, bathrooms, drawers, and closets by law-enforcement officers looking exclusively for evidence of ineligibility or fraud. ${ }^{156}$ In sanctioning these extraordinarily invasive practices in the absence of a warrant or suspicion of wrongdoing, the courts have abandoned any credible pretense of addressing the Fourth Amendment rights of the poor on shared terms with others.

\section{A. Back to the Future: Welfare Reform and the Intrusive State}

\section{Ending Welfare as We Know It}

From the inception of the Aid to Dependent Children program in the early 1930s through the postwar period, federal welfare administration focused on a discretionary social work model that emphasized the exercise of subjective judgment by caseworkers in determining the provision of aid. ${ }^{157}$ Suitable home assessments and other judgments about the worthiness of recipients required social workers during this period to closely monitor poor families, thus "necessitating home visits and other means of surveillance." 158 During the 1960 s, a number of constituencies converged to challenge this model. ${ }^{159}$ Reacting to the perceived bias and inconsistency resulting from the exercise of broad discretion, as well as a sense that the model inappropriately intruded

consider the question, only two have rejected application of the warrant and probable-cause requirement to homes searches used in the investigation of alleged child abuse).

154. Walsh, 240 F. Supp. $2 \mathrm{~d}$ at 746 . This conclusion, however, has not been universally embraced. A district court in Illinois, for example, relied on Wyman to conclude that a warrantless strip search of suspected abuse victims neither implicated the Fourth Amendment nor was unreasonable in the absence of probable cause. Darryl H., 585 F. Supp. at 389-90; see also E.Z., 603 F. Supp. at 1558-59.

155. See infra Part II.B.1.

156. See infra Part II.B.1; see also, e.g., Sanchez v. County of San Diego, 464 F.3d 916 (9th Cir. 2006).

157. See Matthew Diller, The Revolution in Welfare Administration: Rules, Discretion, and Entrepreneurial Government, 75 N.Y.U. L. REV. 1121, 1135-37 (2000).

158. Id. at 1136; see also supra notes $91-93$ and accompanying text.

159. See GILloM, supra note 1 , at 28-29 (referring to "urban militancy, relatively progressive national leadership and local administration, litigation and advocacy by progressive attorneys, the effect of War on Poverty policies, and the impact of mass protest and mobilization"). 
upon the privacy and dignity of the poor, ${ }^{160}$ policy makers responded by shifting toward a more formal, rules-based methodology for the determination of eligibility and benefits. ${ }^{161}$

The result, as Diller describes, was a "welfare system [that] operated through a legal-bureaucratic model. Under this model, administrators dispensed benefits in accordance with a fixed set of generally applicable rules. Recipients had a legal entitlement to receipt of benefits and could challenge adverse decisions both administratively and in court." 162 The new model, based on "a view of poverty that focuses on structural economic issues, rather than individual failings," $" 163$ stressed the concept of entitlement-- "the idea that recipients have a right to benefits when they meet specified eligibility criteria"164 _ and featured "a message that people in poverty can manage their own lives." ${ }^{165}$ A dramatic reduction in the surveillance and monitoring of aid recipients accompanied these changes. ${ }^{166}$ As Gilliom notes, "The level of suspicion, hassle, and investigations dropped as program administrators placed greater emphasis on accepting the terms and condition of poor people's needs as they were presented by the poor themselves." ${ }^{167}$ Thus, just as the Supreme Court sanctioned the use of home visits in its 1971 decision in Wyman, events ironically overtook the litigation and rendered the procedure and related administrative practices largely irrelevant. $^{168}$

These changes, however, did not last long. The "welfare reform" movement that began during the Reagan presidency ${ }^{169}$ and culminated with the passage of transformative federal legislation in $1996^{170}$ challenged the entitlement model of welfare administration as a naïve and counterproductive experiment that made benefits too easy to obtain, too generous, and too difficult to terminate-thus exacerbating rather than alleviating poverty by creating a culture of indolence and dependency among the poor. ${ }^{171}$ In support of this critique, proponents of reform repeatedly

160. See Diller, supra note 157 , at 1136-37, 1143-45; GILLIOM, supra note 1, at 28.

161. See Diller, supra note 157 , at 1137; see also GilloM, supra note 1, at 29.

162. Diller, supra note 157 , at 1126.

163. Id. at 1144.

164. Id.

165. Id. at 1145.

166. See GILLIOM, supra note 1, at 28-29.

167. Id. at 28; see also Susan D. Bennett, "No Relief but Upon the Terms of Coming into the House"-Controlled Spaces, Invisible Disentitlements, and Homelessness in an Urban Shelter System, 104 YALE L.J. 2157, 2184 (1995) (describing an "astonishing burst of regulatory liberalization").

168. See GllLIOM, supra note 1, at 28.

169. See, e.g., IMIG, supra note 14 , at 2.

170. See Personal Responsibility and Work Opportunity Reconciliation Act of 1996 (PRWORA), Pub. L. No. 104-193, 110 Stat. 2105 (codified in scattered sections of the U.S.C.).

171. See, e.g., Michele Estrin Gilman, Poverty and Communitarianism: Toward a Community-Based Welfare System, 66 U. PITT. L. REv. 721, 745 (2005) ("In the 1980s, conservative critics of welfare ... claimed that welfare induced laziness, dependency, promiscuity, immorality, and deviancy among recipients."); Lucie E. White, No Exit:Rethinking "Welfare Dependency" from a Different Ground, 81 GEo. L.J. 1961, 1964 (1993) ("In the early 1980 s, conservative scholars rediscovered the myth that welfare causes persistent poverty and represented it as a serious policy claim."); see also James W. Fox, Jr., Liberalism, Democratic 
conjured the image of the welfare queen first mythologized by President Reagan ${ }^{172}$ to make the case for dramatic change:

[W] $e^{\prime}$ re not talking about characters out of some Steinbeck novel here. ... These recipients ... are flesh and blood women who have become addicted to support that allows them to lead counter-productive lives as parasites of the state. Unlike the poor of the American Depression, they have no work ethic to pass on to their children and their lives are marked with disorder, self indulgence, and sloth. ${ }^{173}$

The depiction of the aid recipient as a champagne-sipping, Cadillac-driving mother of droves ${ }^{174}$ was surreally disconnected from reality ${ }^{175}$ but powerfully evocative of earlier conceptions of the poor: morally defective, indolent, and addicted to the enervating largesse of public assistance that freed the recipient from honest labor. ${ }^{176}$ Many of the tenets underlying President Clinton's pledge to "end welfare as we know it"177 were thus familiar to students of the early poor laws: poverty is not a social or economic phenomenon but rather an individual failing; aid to the poor risks an unhealthy dependence upon it, so government must offer assistance parsimoniously; and the children of the poor are inherently at risk due to the infirmity of their parents. ${ }^{178}$

Citizenship, and Welfare Reform: The Troubling Case of Workfare, 74 WASH. U.L.Q. 103, 109 (1996) ("The true failing of the current welfare system, according to its critics, is not just that it perpetuates poverty, but that it breeds a non-work mentality among the underclass which incapacitates them and excludes them from social citizenship.").

172. See, e.g., Sheryll D. Cashin, Democracy, Race, and Multiculturalism in the TwentyFirst Century: Will the Voting Rights Act Ever Be Obsolete?, 22 WASH. U. J.L. \& PoL'Y 71, 94 (2006) ("On the campaign stump Reagan railed against the 'welfare queen' in Chicago who reportedly had 'eighty names, thirty addresses, twelve social security cards' and tax free income of 'over one hundred and fifty thousand dollars."'); Peter Edelman, The World After Katrina: Eyes Wide Shut?, 14 GEO. J. ON POVERTY L. \& POL'Y 1, 3-4 (2007) ('The backlash politics of welfare cut its teeth on the residents of inner-city America. For most of his listeners, Ronald Reagan's 'story' of the 'welfare queen' who drove to the grocery store in her white Cadillac to buy the best steak with her food stamps evoked an image of an African American inner-city single mother probably living in a public housing project.").

173. Vivyan Adair, From Good Ma to Welfare QueEn: A Genealogy of the Poor WOMAN IN AMERICAN Literature, PHOTOGRAPHY, AND CULTURE 33 (2000) (quoting Tommy Thompson, Speech at the University of Wisconsin-Madison (Sept. 1995)); see also White, supra note 171, at $1962 \mathrm{n} .3$ (discussing Wisconsin's early experiments in welfare reform).

174. See, e.g., GILlom, supra note 1, at 30-31; DAVID ZuCchino, The MYTH OF THE

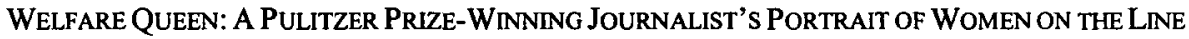
13 (1997); April Land, Children in Poverty: In Search of State and Federal Constitutional Protections in the Wake of Welfare "Reforms," 2000 UTAH L. REv. 779, 811; supra note 172.

175. See, e.g., ZUCCHINO, supra note 174, at 13-14; Gilman, supra note 171, at 746-50; cf. ZuCCHINO, supra note 174, at 65 ("Reagan was referring to a forty-seven-year-old Chicago woman named Linda Taylor, who had indeed been charged with welfare fraud. But reporters who looked into the case that year found that Reagan had lavishly embellished a tale of petty fraud. Taylor was charged with defrauding the state of $\$ 8,000$, not $\$ 150,000$. She was charged with using four aliases, not eighty.").

176. See, e.g., Quigley, Backwards, supra note 54, at 103-07.

177. Remarks on Welfare Reform in Kansas City, Missouri, 1 PUB. PAPERs 1075, 1076 (June 14, 1994).

178. See, e.g., Quigley, Backwards, supra note 54, at 101; see also Gilman, supra note 171, 
By the mid-1990s, these principles enjoyed broad currency among legislators and policy makers of both major parties. ${ }^{179}$ With the political establishment largely allied against the poor in its judgment that strong medicine was required to end the posited culture of personal irresponsibility and intergenerational welfare dependence, ${ }^{180}$ Congress enacted sweeping changes to public assistance policy. ${ }^{181}$ The new legislation eliminated Aid to Families with Dependent Children (AFDC), the prior federal entitlement program, and replaced it with a block-grant program to the states known as Temporary Assistance to Needy Families (TANF). ${ }^{182}$ TANF, in turn, "grants substantial flexibility to states to determine how to administer" federal welfare funds, "explicitly ends the entitlement status of assistance for needy children and families, imposes comprehensive work requirements, and initiates a five year lifetime limit on those seeking assistance." 183 The overarching objective of TANF is to dramatically reduce the number of individuals receiving public assistance by moving them into the workforce. $^{184}$

The primary measure of success under the new legislation is caseload reduction, ${ }^{185}$ and the statutory scheme establishes significant incentives to achieve that outcome. ${ }^{186}$ "[S]tates are given fixed block grants, which give them increased financial stakes in reducing their caseloads. States with increasing caseloads simply cannot turn to the federal government for more aid. States with declining caseloads end up with a windfall of federal dollars." 187 In many states, the same incentive structure applies at the local level; California, for example, provides a block grant to local entities administering TANF and allows them to keep whatever sum is not spent on benefits. ${ }^{188}$ As a result, caseworkers face insistent demands to move recipients into any available job- " [a]pparently, the pay cannot be too low, the hours too irregular, or the commute too far to make a job unsuitable." 189

These and related changes "have made assistance for poor people much more difficult to secure and, if secured, much more difficult to retain." 190 In the four years

at 724-25 ("The theoretical underpinning of [welfare reform] is that personal character flaws cause poverty."); Hafetz, supra note 3, at 227-28; White, supra note 171, at 1963.

179. See, e.g., Fox, supra note 171, at 103; cf. Gilman, supra note 171, at 741 ; White, supra note 171 , at 1963.

180. See Peter S. Goodman, From Welfare Shift in '96, a Reminder for Clinton, N.Y. TiMES, Apr. 11, 2008, at A1; Robert Pear, Clinton to Sign Welfare Bill That Ends U.S. Aid Guarantee and Gives States Broad Power, N.Y. TIMES, Aug. 1, 1996, at A1; see also Gilman, supra note 171 , at 741 .

181. Personal Responsibility and Work Opportunity Reconciliation Act of 1996 (PRWORA), Pub. L. No. 104-193, 110 Stat. 2105 (codified in scattered sections of the U.S.C.).

182. Land, supra note 174, at 781-83. See generally Quigley, Backwards, supra note 54, at $101-02$.

183. Quigley, Backwards, supra note 54, at 102; see also Diller, supra note 157, at 1146.

184. See, e.g., 42 U.S.C. § 601(a)-(b) (2006); Diller, supra note 157, at 1183-84.

185. Diller, supra note 157 , at 1183.

186. Id. at $1178-80$.

187. Id. at 1178 .

188. Id. at 1180 .

189. Id. at 1171; see also id. at 1184 ("The goal is to get recipients off benefits and into jobs, with little concern about the quality of the jobs, the overall change in incomes, or the well-being of recipients.").

190. Quigley, Backwards, supra note 54, at 102; see also Diller, supra note 157, at 1179 
following enactment of TANF, the number of individuals receiving federally funded welfare assistance declined by nearly $50 \%$. ${ }^{191}$ Poverty, however, continues unabated. ${ }^{192}$ As Gilman summarizes, "the actual living situations of most current and former welfare recipients are bleak, because most people who leave welfare remain below the poverty line, while others are unemployed and disconnected from the welfare system." Facing relentless pressure to move off the welfare rolls, TANF recipients often transition into low-wage jobs with few benefits and face increased expenditures for child care, transportation, medical care, and related expenses, while others who do not secure employment simply "disappear from the system." impact of a national poverty strategy focused on caseload reduction is the fact that approximately half of all families who are eligible for assistance under TANF do not receive it. $^{195}$

\section{Home Visits in the New Regime}

An important element of this massive restructuring effort has been the devolution of discretionary responsibility to local officials ${ }^{196}$-again, in keeping with poor relief of previous centuries. ${ }^{197}$ In view of the statutory focus on caseload reduction, localities have devoted significant attention to reducing the number of recipients at the front-end by imposing stringent and frequently demeaning verification procedures governing applications for aid. ${ }^{198}$ As Mulzer explains, "In the hands of 'goal-oriented' welfare agencies, verification procedures become much more than a means of error or fraud control, leading to routine invasions of claimants' privacy and causing many eligible individuals to be denied benefits or discouraged from ever applying for them." new and aggressive investigative techniques associated with this emerging "verification

("[PRWORA] places a premium on achieving caseload reduction through means that make it more difficult for 'eligible' individuals to obtain benefits initially and to maintain eligibility once on the rolls.").

191. Gilman, supra note 171, at $741 \mathrm{n} .85$; see also Diller, supra note 157, at 1123; Land, supra note 174 , at 818 .

192. See, e.g., Gilman, supra note 171 , at $741-43$.

193. Id. at 742; see also Land, supra note 174, at 783 (noting an "increase in extreme child poverty" tied to PRWORA).

194. Gilman, supra note 171, at 742; see also Tonya L. Brito, The Welfarization of Family Law, 48 U. KAN. L. REV. 229, 277 (2000).

195. Gilman, supra note 171, at 742; Amy Mulzer, Note, The Doorkeeper and the Grand Inquisitor: The Central Role of Verification Procedures in Means-Tested Welfare Programs, 36 COLUM. HUM. RTS. L. REV. 663, 665 (2005).

196. See Diller, supra note 157 , at $1145-86$.

197. Quigley, Backwards, supra note 54, at 106-07.

198. Mulzer, supra note 195, at 674-78; see id. at 674 ("This [verification] practice has been fueled by a new method of welfare administration, which relies less on formal policymaking and more on signaling and intimation among policymakers, administrators, and front-line workers."); see also GILloM, supra note 1, at 28; Lawrence Zelenak, Tax or Welfare? The Administration of the Earned Income Tax Credit, 52 UCLA L. REV. 1867, 1878 (2005).

199. Mulzer, supra note 195, at 666; see also id. at 674 (describing the use of administrative procedures "aimed not at rooting out fraud but at discouraging claimants from applying in the first place"). 
extremism"200 are designed not merely to ferret out applications submitted by the posited legions of welfare queens ${ }^{201}$ but also "to augment the hassle, intimidation, and humiliation of applicants with an eye toward the policy goal of deterring all but the most desperate from seeking aid." 202 This "[i]nformal rationing allows states to reduce welfare rolls without cutting eligibility or benefit levels, leading the public to believe that the drop was caused by a genuine reduction in need."203

Among the local verification methods devised to promote these objectives is a resurrected variant of the traditional home visit. However, rather than follow the template of the visits depicted in Wyman-where caseworkers met with families to promote rehabilitative services and the care of children - this new version is explicitly investigatory in design and conducted by law-enforcement officers whose sole purpose is to search the home for evidence of ineligibility or fraud. ${ }^{204}$ Verification programs in San Diego County, California, and Milwaukee County, Wisconsin, exemplify this aggressive approach, ${ }^{205}$ while California's Los Angeles County has implemented a moderated version of the same strategy. ${ }^{206}$ While there is significant variation among these and related programs in other jurisdictions, ${ }^{207}$ several shared attributes broadly distinguish this new generation of home visits from the procedures at issue in Wyman. ${ }^{208}$

200. Id. at 674; see also Bennett, supra note 167, at 2164 .

201. See, e.g., Mulzer, supra note 195, at 688-89; cf. id. at 683 ("[P]ublic support for welfare is complicated by concerns about claimants' moral status and deservingness. Stringent and invasive verification procedures stigmatize the receipt of benefits and express these concerns to claimants."). See generally Bennett, supra note 167.

202. GLLLIOM, supra note 1, at 40 (arguing that "a broad[] cultural shaming of the poor" both "stigmatize[s] and frighten[s]" the indigent and leads to a corresponding decline in applications for aid); see, e.g., Mulzer, supra note 195, at 675 ("Some state and local agencies are using verification procedures to stigmatize and embarrass claimants, not merely to reduce the number of completed applications, but seemingly for the sake of stigma itself.").

203. Mulzer, supra note 195 , at 675 .

204. See Sanchez v. County of San Diego, 464 F.3d 916, 918-19 (9th Cir. 2006) (describing San Diego County's program); id. at 934-36 (Fisher, J., dissenting); S.L. v. Whitburn, 67 F.3d 1299, 1301-03 (7th Cir. 1995) (describing Milwaukee County's program); cf. Hafetz, supra note 3, at 228 ("The increased scrutiny of recipients to enforce measures like work requirements has led to a rebirth of unannounced home visits in some states."); Bennett, supra note 167, at 2172 n. 52 .

205. See Sanchez, 464 F.3d at 918-19; id. at 934-36 (Fisher, J., dissenting); Whitburn, 67 F.3d at 1301-03.

206. Smith v. L.A. County Bd. of Supervisors, 128 Cal. Rptr. 2d 700, 703-05 (Ct. App. 2002) (describing Los Angeles County's program).

207. See, e.g., Roberson v. Giuliani, No. 99 Civ. 10900 (DLC), 2000 WL 760300, at *2-3 (S.D.N.Y. June 12, 2000) (describing New York City's home visit program); Bennett, supra note 167, at 2172 n.52 (describing program in New Hampshire); Mulzer, supra note 195, at 676 (describing New York City's program).

208. Sanchez v. County of San Diego, 483 F.3d 965, 967 (9th Cir. 2007) (Pregerson, J., dissenting from denial of rehearing en banc) (" $[\mathrm{T}]$ he simple fact of the matter is that a home visit in Sanchez is fundamentally different from a home visit in Wyman."). 


\section{a. San Diego County}

The most aggressive of the new programs is San Diego County's "Project $100 \%$ "named in recognition of its requirement that $100 \%$ of the county's aid applicants must submit to its demands. ${ }^{209}$ Conceived and implemented in 1997 by the San Diego District Attorney's Office, ${ }^{210}$ Project $100 \%$ requires that every aid applicant in the county submit to a highly invasive home search conducted by sworn law-enforcement investigators from the District Attorney's Public Assistance Fraud Division (PAFD). ${ }^{211}$ The program is partnered with a second and more aggressive search protocol reserved for those applicants whose initial paperwork triggers some cause for suspicion. ${ }^{212}$ Project $100 \%$ thus applies exclusively to applicants for whom there is no basis to suspect any fraud, wrongdoing, or grounds for ineligibility. ${ }^{213}$ Since its inception, Project $100 \%$ has resulted in tens of thousands of suspicionless home searches. ${ }^{214}$

The sole purpose of Project $100 \%$ is to detect fraud or ineligibility. ${ }^{215}$ The fraud investigators conducting the searches are expressly instructed to offer no guidance or assistance to aid applicants during the course of the home visit, leaving that responsibility instead to caseworkers in the county's Health and Human Services Department. ${ }^{216}$ When asked about the possibility that the visits might have some rehabilitative component, the chief of PAFD scoffed at the proposition: "I'm trying to envision what rehabilitation would be under those circumstances. Get off the couch. Get a job. I don't know. So, no ... . I don't envision rehabilitation as a part of that. I can't even imagine what that would look like."217 Moreover, while the denial of aid is the only sanction if a search uncovers evidence that a pending application is fraudulent, ${ }^{218}$ no such restriction applies to evidence of other crimes uncovered by

209. See Plaintiffs-Appellants' Opening Brief at 9-10, Sanchez v. County of San Diego, 464 F.3d 916 (9th Cir. 2006) (No. 04-55122), 2004 WL 1949000, at*9_*10.

210. The District Attomey's Office proposed Project $100 \%$ to the County Board of Supervisors without input from or consultation with the county's welfare agency, which it suspected would oppose the proposal. Id. at 10-11. When the details of Project $100 \%$ searches were described to him, the director of the welfare agency responded: "[I]t certainly would be inappropriate to treat anyone applying for benefits like a criminal ... . And it certainly would not be consistent with the values we espoused at the Health and Human Services Agency." Id. at 14.

211. See Sanchez, 464 F.3d at 918-20.

212. Plaintiffs-Appellants' Opening Brief, supra note 209, at 19.

213. Sanchez, 464 F.3d at 918 ("[A]ll San Diego County residents who submit welfare applications ... and are not suspected of fraud or ineligibility, are automatically enrolled in Project 100\%."); Plaintiffs-Appellants' Opening Brief, supra note 209, at 19.

214. Sanchez v. County of San Diego, No. 00CVI467JM(JFS), 2001 WL 1830236, at *4 (S.D. Cal. Dec. 27, 2001) (granting, in part, a motion for class certification).

215. Sanchez, 464 F.3d at 919; id. at 935 (Fisher, J., dissenting) ("According to the defendants themselves, the program's objective is not to assist the needy, but to 'increase welfare fraud prevention efforts and to increase program integrity."').

216. Id. at 935 (Fisher, J., dissenting) (Project 100\% investigators are "trained not to give advice to applicants" (emphasis in original)); Plaintiffs-Appellants' Opening Brief, supra note 209 , at 16 .

217. Plaintiffs-Appellants' Opening Brief, supra note 209, at 15-16.

218. Sanchez, 464 F.3d at 919. 
investigators inside the home. ${ }^{219}$ Accordingly, Project $100 \%$ searches can and do trigger prosecutions for other criminal conduct, ${ }^{220}$ and "[o]n occasion, the investigators even arrange for arrests., 221

The protocol for a Project $100 \%$ search illustrates the highly invasive character of the intrusion. When applicants first seek public assistance from the county's welfare agency, "they are informed that they will be subject to a mandatory home visit in order to verify their eligibility." 222 Applicants do not receive an appointment time and are not even told what day the search will occur, although it typically takes place within ten days of the initial application. ${ }^{223}$ Instead, investigators in plainclothes appear at the door, "identify themselves to applicants by showing either a metal badge or folding identification card with the District Attorney logo," and request entry. ${ }^{224}$ Applicants are told from the outset that if they do not permit the search, they will receive no aid. ${ }^{225}$ Once inside, investigators may spend an hour or more ${ }^{226}$ interviewing the applicant regarding eligibility criteria and conducting a "walk-through" of the home. ${ }^{227}$ During the interview, investigators "ask to see bank statements, pay stubs, tax returns, benefit check stubs, and other documents . . . [N]othing is "off-limits." ${ }^{228}$ In the course of the subsequent walk-through, investigators may search any space within the home that they deem relevant to verification, ${ }^{229}$ and an applicant's refusal to permit inspection of any portion of the home will result in the denial of benefits. ${ }^{230}$ Investigators thus "may request to look at the contents of bedrooms, closets, kitchens, bathrooms, medicine cabinets and drawers in search of evidence of ineligibility or fraud."231 Focusing primarily on evidence of an undisclosed male in the household, investigators count toothbrushes, look for men's bath products, examine the contents of laundry baskets,

219. Id. at 919 n.3.

220. Id.; see also Sanchez v. County of San Diego, 483 F.3d 965, 966-67 (9th Cir. 2007) (Pregerson, J., dissenting from denial of rehearing en banc).

221. Sanchez, 464 F.3d at 934 n.1 (Fisher, J., dissenting).

222. Id. at 919 (majority opinion).

223. Sanchez v. County of San Diego, No. 00CV1467JM(JFS), 2003 WL 25655642, at *2 (S.D. Cal. Mar. 10, 2003), aff'd, 464 F.3d 916 (9th Cir. 2006).

224. Sanchez, 464 F.3d at 934 n.2 (Fisher, J., dissenting); Sanchez, 2003 WL 25655642, at *1; see also Plaintiffs-Appellants' Opening Brief, supra note 209, at 21-22.

225. Sanchez, 2003 WL 25655642, at *2; Plaintiffs-Appellants' Opening Brief, supra note 209 , at 20 (noting that an orientation video viewed by all aid applicants warns that "[i]f you do not cooperate [with the PAFD investigator who visits the home], your benefits will be stopped or denied.").

226. Plaintiffs-Appellants' Opening Brief, supra note 209, at 21.

227. Sanchez, 464 F.3d at 918; Sanchez, 2003 WL 25655642, at *2.

228. Plaintiffs-Appellants' Opening Brief, supra note 209, at 22-23.

229. Sanchez, 2003 WL 25655642 , at $* 8$ n.8 ("[N]o specific protocol limits where the investigator may look....").

230. Plaintiffs-Appellants' Opening Brief, supra note 209, at 27 n.20 ("[E]ligibility technicians deny applications if the Fraud Investigator reports that an applicant refused to answer questions, or refused full entry to her residence.").

231. Sanchez, 464 F.3d at 936 (Fisher, J., dissenting). Failure to provide such consent constitutes noncompliance and will lead to the denial of benefits. See Sanchez, 2003 WL 25655642 , at *2. 
open refrigerators, and explore the contents of trash cans and dresser drawers. ${ }^{232}$ Investigators do not open drawers or closets themselves but instead ask the applicants to do so. ${ }^{233}$ One investigator explained that this is done to "[p]rotect yourself, safety. I don't want to stick my hand in anything. I want her to open everything and let me look." 234 Once the search is completed, investigators transmit their conclusions to caseworkers in the county's welfare agency. ${ }^{235}$ Unless the investigator indicates that the home visit was successful, the caseworker will deny the application. ${ }^{236}$

Notably, San Diego County gathers no data that isolates the rate at which Project $100 \%$ searches detect fraud or ineligibility. ${ }^{237}$ Instead, the county combines Project $100 \%$ with a parallel allegation-based investigative program to generate aggregate statistics addressing the outcome of all welfare-related investigations, both suspicionless and cause-based. ${ }^{238}$ Accordingly, the county has no data addressing the efficacy of Project $100 \%$ that is not embedded with and skewed by unrelated information generated by the investigation of applicants for whom the county has cause to suspect fraud or ineligibility - searches that presumably will yield a far higher rate of denied applications. ${ }^{239}$ Evidently by design, the county is incapable of assessing the effect of its program.

\section{b. Milwaukee and Los Angeles Counties}

While Project $100 \%$ defines the outer perimeter of aggressive search practices used to verify eligibility for aid, other jurisdictions have developed similar home-visit programs that share many of the same characteristics. Policies adopted by the counties of Milwaukee and Los Angeles exemplify these closely related verification strategies. $^{240}$

Milwaukee County's search program, dating to the early period of welfare reform, began as a local initiative and preceded the 1996 federal legislation by several years. ${ }^{241}$ The program incorporates many of the features of San Diego County's approach: the

232. Sanchez, 2003 WL 25655642, at *2, *8 n.8; Plaintiffs-Appellants' Opening Brief, supra note 209 , at 23-25.

233. Plaintiffs-Appellants' Opening Brief, supra note 209, at 24-25.

234. Id. at 25.

235. Sanchez, 464 F.3d at 919 n.1.

236. Plaintiffs-Appellants' Opening Brief, supra note 209, at 27 n.20; see also Sanchez, 464 F.3d at 919.

237. Plaintiffs-Appellants' Opening Brief, supra note 209, at 27-28.

238. Id.

239. Cf. Sanchez, 464 F.3d at 928 ("Appellants argue that there is no statistically significant evidence that Project $100 \%$ has actually reduced welfare fraud. The County, however, produced data showing that, during the five-year period during which Project $100 \%$ was implemented, the overall denial rate increased from $40.6 \%$ to $47.7 \%$...." (emphasis added)); County of San Diego's Opposition to Petition for Writ of Certiorari at 34-35, Sanchez v. County of San Diego, 128 S. Ct. 649 (2007) (No. 07-211), 2007 WL 3068439 (arguing that "the home visit program has been successful" based on aggregate data).

240. S.L. v. Whitburn, 67 F.3d 1299 (7th Cir. 1995); Smith v. L.A. County Bd. of Supervisors, 128 Cal. Rptr. 2 d 700 (Ct. App. 2002).

241. See Bennett, supra note 167 , at 2172 n.52; cf. Whitburn, 67 F.3d at $1301-02$. 
warrantless searches are unscheduled, ${ }^{242}$ benefits are typically contingent upon consent to entry; ${ }^{243}$ caseworkers play no role in the investigation, which is instead carried out by a private investigative service (but not by sworn law-enforcement investigators, as used in Project $100 \%)$; ${ }^{244}$ and the searches are designed exclusively to uncover evidence of fraud or ineligibility, with no rehabilitative component. ${ }^{245}$ The program differs from Project $100 \%$, however, in some significant respects as well. Most notably, Milwaukee's home searches do not target all applicants but instead just those whose initial submissions are deemed insufficient to verify eligibility. ${ }^{246}$ Once inside the home, however, the investigators scrutinize the dwelling with the same intensity that characterizes a Project 100\% search: "Field representatives may ask to see areas of the residence, and they can ask for permission to inspect closets, cabinets, attics, basements, garages, etc. "247

The County of Los Angeles recently instituted a home search program as well, although its approach lacks some of the harshest features of Project $100 \%$. In Los Angeles, as in San Diego, a home visit is a condition of eligibility for all TANF applicants in the four "pilot" districts subject to the new search program. ${ }^{248}$ The visits are unscheduled and may occur at any point during a ten-day period following the submission of an aid application. ${ }^{249}$ Unlike San Diego and Milwaukee, however, Los Angeles claims to pursue "the dual purposes of eliminating welfare fraud and identifying additional services that can help with family needs." ${ }^{250}$ In keeping with the rehabilitative component of its program, Los Angeles County employs "eligibility workers" rather than law enforcement investigators to conduct home visits ${ }^{251}$ and does not refer applicants for criminal prosecution based on the search results. ${ }^{252}$ The "walkthroughs" under the Los Angeles program are also less intense than the searches conducted in San Diego and Milwaukee: eligibility workers are trained to "'look[] for

242. Whitburn, 67 F.3d at 1302.

243. Id. at 1308. In upholding Milwaukee's search program, Judge Manion of the Seventh Circuit acknowledges that "benefits may be withheld or withdrawn if an applicant does not allow the home visit," but emphasizes that "[t]here is no evidence or reason to believe that an applicant who declines the home visit will be denied benefits even if satisfactory verification of eligibility is provided by some other means." $I d$. The latter scenario is presumably quite unusual, since applicants will likely produce all available documentation before inviting the intrusion and inconvenience of an unscheduled home visit.

244. See id. at 1302.

245. See id. at 1308 ("Although some of [the Wyman] factors related to the caseworker's duty to ensure the health and safety of children receiving AFDC benefits, many of the considerations emphasized by the Court apply in this case"; the court then discusses fiscal integrity and fraud detection).

246. See id. at 1302.

247. Id.

248. Smith v. L.A. County Bd. of Supervisors, 128 Cal. Rptr. 2d 700, 702-04 (Ct. App. 2002).

249. Appellants' Opening Brief at 10-11, Smith v. L.A. County Bd. of Supervisors, 128 Cal. Rptr. 2d. 700 (Ct. App. 2002) (No. B150973), 2002 WL 32152027, at *10-*11.

250. Smith, 128 Cal. Rptr. 2d at 703-04.

251. See id. at 704-05.

252. Id. at 704. 
the obvious things that are just right out in front of you""253 and "are prohibited from opening drawers or closets during their walk-through of the home."254

Unlike San Diego, Los Angeles County collects data addressing the efficacy of its program. During the first six months of implementation, 120 of the 4813 home visits conducted under the pilot program-approximately $2.5 \%$ of the total-identified "conditions of ineligibility resulting in denial of the application." ${ }^{, 255}$ Accordingly, of the nearly 5000 suspicionless home visits completed by Los Angeles County during the initial phase of its verification program, $97.5 \%$ were futile.

\section{B. Constitutionalizing the Modern Home Visit}

The home-visit policies implemented in San Diego, Milwaukee, and Los Angeles have each faced and withstood constitutional challenge. ${ }^{256}$ In upholding the programs, courts have relied on two primary rationales: first, that the holding in Wyman authorizes the practices; and, second, that the contemporary special-needs doctrine independently justifies the intrusions. ${ }^{257}$ Neither rationale withstands scrutiny.

253. Id. at 705 (quoting training instructions for eligibility workers).

254. Id. at 712. There is evidence, however, that this restriction is not always honored. See Appellants' Opening Brief, supra note 249, at 19 ("[T] he home call worker looked through [the applicant's] apartment and asked her to open all the closet doors and dresser drawers, including her underwear drawer.").

255. Smith, 128 Cal. Rptr. 2d at 705.

256. Sanchez v. County of San Diego, 464 F.3d 916 (9th Cir. 2006) (San Diego); S.L. v. Whitburn, 67 F.3d 1299 (7th Cir. 1995) (Milwaukee); Smith, 128 Cal. Rptr. 2d 700 (Los Angeles).

257. The courts have also relied on the proposition that the searches are consensual and therefore permissible under the consent doctrine. The question whether a public benefit may be conditioned on the sacrifice of a constitutional right-here, the Fourth Amendment-has been the subject of decades of conflicting commentary and decisional law that is beyond the scope of this Article to address. See, e.g., Richard A. Epstein, Foreword: Unconstitutional Conditions, State Power, and the Limits of Consent, 102 HARV. L. REV. 4, 6 (1988) (describing the problem as "the basic structural issue that for over a hundred years has bedeviled courts and commentators alike under the mysterious title of 'unconstitutional conditions"); Kathleen $\mathbf{M}$. Sullivan, Unconstitutional Conditions, 102 HARV. L. REv. 1413, 1415-16 (1989) (observing that the decisional law in the area is "a minefield to be traversed gingerly").

Apart from the unconstitutional-conditions issue, however, the concrete setting in which consent is obtained in the context of welfare home visits is itself exceptionally coercivemanifest in the fact that the aid applicant must choose between asserting her constitutional right and securing the means to feed, clothe, and shelter her children. See supra note 107; see also, e.g., Sanchez v. County of San Diego, 483 F.3d 965, 968-69 (9th Cir. 2007) (Pregerson, J., dissenting from the denial of rehearing en banc); Recent Case, Constitutional Law-Fourth Amendment-Ninth Circuit Upholds Conditioning Receipt of Welfare Benefits on Consent to Suspicionless Home Visits-Sanchez v. County of San Diego, 464 F.3d 916 (9th Cir. 2006), 120 HARV. L. REV. 1996, 2001-02 (2007) [hereinafter Constitutional Law-Fourth Amendment]. Data from Los Angeles's pilot search program strongly corroborates this conclusion. Of the 4800 searches that the county conducted during the first six months of its program, a total of eight applicants stood on their privacy rights, refused to provide consent, and accordingly sacrificed subsistence aid for their children and dependents. Smith, 128 Cal. Rptr. $2 \mathrm{~d}$ at 706. 


\section{Reinventing Wyman}

Although Wyman notably departed from Fourth Amendment doctrine to exempt the poor from its traditional protections, the reach of the decision was limited in evident respects. In explaining its conclusion that the home visit was a reasonable intrusion for purposes of the Fourth Amendment, Wyman offered a list of eleven factors that purportedly distinguished the visit from other types of government searches. ${ }^{258}$ The enumerated considerations evoke a quite specific conception of the encounter: a paternalistic interaction between aid recipients and their social workers that was relatively benevolent, restrained, and designed to promote rehabilitative as well as investigatory objectives. ${ }^{259}$ Although the new generation of home search programs incorporates few, if any, of these moderating characteristics, courts have nevertheless declared that Wyman controls and dictates that these "radically different" ${ }^{260}$ programs be upheld. ${ }^{261}$

\section{a. The Rehabilitative Purpose of the Visit}

Foundational to Wyman's analysis was the rehabilitative purpose of the challenged home visits. At the outset of the opinion, in explaining its conclusion that the visit did not fall within the reach of the Fourth Amendment, the Court turned first to the objectives of the visiting social worker:

It is ... true that the caseworker's posture in the home visit is perhaps, in a sense, both rehabilitative and investigative. But this latter aspect, we think, is given too broad a character and far more emphasis than it deserves if it is equated with a search in the traditional criminal law context. ${ }^{262}$

The Court reiterated the theme as it argued that the visits, even if considered searches under the Fourth Amendment, were reasonable and thus permissible:

The emphasis of the [program] is upon the home, upon "close contact" with the beneficiary, upon restoring the aid recipient "to a condition of self-support," and upon the relief of his distress. The federal emphasis is no different. It is upon "assistance and rehabilitation," upon maintaining and strengthening family life, and upon "maximum self-support and personal independence consistent with the maintenance of continuing parental care and protection.,"263

258. See supra Part I.C.

259. See supra Part I.C.

260. Sanchez, 464 F.3d at 938 (Fisher, J., dissenting).

261. See id. at 921 (majority opinion) ("Wyman directly controls the instant case."); Whitburn, 67 F.3d. at 1308; cf. Smith, 128 Cal. Rptr. 2d at 712-13. Indeed, while the Ninth Circuit acknowledged that Wyman "arguably has been called into question by the Supreme Court's subsequent Fourth Amendment jurisprudence," it nonetheless declared that the opinion "still controls this case because of its 'direct application,' despite the reasoning of these later administrative search cases." Sanchez, 464 F.3d. at 922 n.8.

262. Wyman v. James, 400 U.S. 309, 317 (1971).

263. Id. at 319 (citations omitted). 
The Court continued: "[T] he visit is 'the heart of welfare administration'; . . it affords 'a personal, rehabilitative orientation, unlike that of most federal programs'; and ... . the 'more pronounced service orientation' effected by Congress . . . 'gave redoubled importance to the practice of home visiting.,"264 "The caseworker," the Court concluded, "is not a sleuth but rather, we trust, is a friend to one in need." ${ }^{265}$ While the opinion simultaneously and somewhat schizophrenically stressed that the visitors skeptically assessed the veracity and need of aid recipients, ${ }^{266}$ the supportive function of the visiting social worker played a central and arguably predominant role in the Court's conclusion that the challenged practice was constitutional. ${ }^{267}$

Of the three contemporary search programs considered by the lower courts, policies implemented by San Diego and Milwaukee Counties are expressly investigatory in nature, with no rehabilitative or service component. ${ }^{268}$ Rather than questioning the application of Wyman to such divergent facts, the Seventh and Ninth Circuits dismissed or ignored the distinction. ${ }^{269}$ The approach of the Ninth Circuit was summarized at oral argument by Judge Andrew Kleinfeld, who joined the Sanchez majority in upholding Project $100 \% .{ }^{270}$ In response to counsel's argument that the rehabilitative and service objectives were a key distinguishing feature in Wyman, Kleinfeld simply denied the fact: "Nah, ... that wasn't Wyman. They weren't there to help them. It was a . . caseworker investigation." 71 Thus in the retelling, Wyman's "friend to one in need" actually "[wasn't] there to help" at all: a frank distortion of the opinion that dramatically expands Wyman's reach.

The majority opinion in Sanchez carries forward Judge Kleinfeld's approach. The analysis begins with the proposition that "rehabilitative purpose," as used in Wyman, merely refers to one of the encompassing statutory objectives of all federal welfare laws, which "are the same background against which San Diego County's welfare program is administered" 272 -and, thus, that "there is no greater showing of a rehabilitative purpose [in Wyman] than there is in this case."273 This remarkable assertion ignores two prominent facts. First, under San Diego's program, the rehabilitative and service objectives of the federal scheme are carried out independently of the home searches at issue, which instead focus exclusively on investigatory objectives-unlike in Wyman, where the home visits served both

264. Id. at $319-20$ (citations omitted).

265. Id. at 323 .

266. See id. at 344 (Marshall, J., dissenting).

267. See supra notes 262-65 and accompanying text; Wyman, 400 U.S. at 317 (majority opinion) ("[T]his latter [investigatory] aspect, we think, is given too broad a character and far more emphasis than it deserves ...."); see also Sanchez v. County of San Diego, 464 F.3d 916, 933 (9th Cir. 2006) (Fisher, J., dissenting).

268. See supra notes $215-21 \& 245$ and accompanying text; see also Sanchez, 464 F.3d at 934-35 (Fisher, J., dissenting).

269. Sanchez, 464 F.3d at 921 nn.6-7; S.L. v. Whitburn, 67 F.3d 1299, 1309 (7th Cir. 1995).

270. Sanchez, 464 F.3d at 918 .

271. Audio file: Oral Argument, Sanchez, 464 F.3d 916 (No. 04-05122) (remarks of Kleinfeld, J., at 5:12) (on file with the Indiana Law Journal).

272. Sanchez, 464 F.3d at $921 \mathrm{nn} .6-7$.

273. Id. at 921 n.6. 
rehabilitative and investigatory purposes, as the Supreme Court emphatically and repeatedly underscored. ${ }^{274}$ Second, the claim ignores Wyman's specific emphasis on the concrete rehabilitative relationship established between caseworkers and the aid recipients to whom they purportedly serve as "a friend to one in need."275 That personal, assisting relationship, developed within the context of the recipient's home, played a central role in Wyman's characterization of the reasonableness of the visits at issue. ${ }^{276}$ To equate "rehabilitation" as used in this concrete sense with San Diego's purely investigatory search program, simply because both proceed under a broad federal grant of authority that includes rehabilitation among its general statutory goals, is an impossible stretch. San Diego County may seek to promote the rehabilitation of aid recipients, but it most assuredly does not do so while searching their dresser drawers.

The Sanchez majority alternatively asserts that the rehabilitative purpose of a Wyman visit, to the extent that it might differ from the objectives of Project $100 \%$, "is relevant only insofar as it indicates that the home visits are not intended as searches conducted in furtherance of a criminal investigation."277 In turn, because San Diego does not pursue criminal sanctions in cases where a Project $100 \%$ search uncovers evidence that a pending application might be fraudulent, ${ }^{278}$ the court concludes that any distinction between the rehabilitative objectives in Wyman and Sanchez is irrelevant. ${ }^{279}$

There are two significant problems with this argument. First, it ignores the substantial criminal-enforcement dimensions of San Diego's home search program, under which investigators "make referrals for criminal investigation if they discover evidence of contraband, child abuse or a subject with outstanding felony warrants," and "[o]n occasion . . . even arrange for arrests." ${ }^{\text {280 }}$ Second, the argument again defies the Wyman text. Wyman did not address the program's rehabilitative and service objectives solely with reference to whether the home visit should be analogized to a criminal search, but instead stressed those purposes as separate considerations that independently supported the reasonableness of the intrusion. Thus, in the Court's enumeration of eleven factors demonstrating the reasonableness of the challenged practice, three solely addressed the rehabilitative and service objectives of the visit; ${ }^{281}$ two conversely addressed the absence of criminal consequences, with no reference to service or rehabilitation; ${ }^{282}$ and one factor addressed the two considerations in

274. See supra notes 262-65; Sanchez, 464 F.3d at 935 n. 4 (Fisher, J., dissenting). Indeed, the Wyman Court expressly underscored that the home visit under review directly facilitated the statute's rehabilitative objectives. Wyman v. James, 400 U.S. 309, 319-20 (1971) ("[T] he 'more pronounced service orientation' effected by Congress ... 'gave redoubled importance to the practice of home visiting."').

275. See supra notes $262-67$ and accompanying text.

276. See supra notes $262-67$ and accompanying text.

277. Sanchez, 464 F.3d at 921 n.7.

278. Id. at 919; see also Sanchez v. County of San Diego, No. 00CV1467JM(JFS), 2003 WL 25655642, at *2 (S.D. Cal. Mar. 10, 2003), aff'd, 464 F.3d 916 (9th Cir. 2006).

279. Sanchez, 464 F.3d at 921 n.7.

280. Id. at $934 \mathrm{n} .1$ (Fisher, J., dissenting).

281. Wyman v. James, 400 U.S. 309, 318-20 (1971) (factors one, four, and five).

282. Id. at 321,323 (factors seven and ten). 
conjunction. ${ }^{283}$ The claim that Wyman fused the concerns is irreconcilable with the terms of the opinion itself.

For the balance of its analysis, Sanchez makes no reference to the supportive objectives of the home visit, focusing instead on other Wyman factors that overlap with San Diego's program. ${ }^{284}$ Having thus read rehabilitation out of the text, the Ninth Circuit recasts the Wyman visit as an investigatory effort-like Project $100 \%$ - to thwart welfare fraud. ${ }^{285}$ So fictionalized, Wyman now stands for the proposition that a warrantless, suspicionless, and purely investigatory search of the most private and intimate spaces within an aid applicant's home, conducted without notice by lawenforcement fraud investigators, operates outside the reach of the Fourth Amendment. ${ }^{286}$

The Seventh Circuit's approach in upholding Milwaukee's search program mirrors the Ninth Circuit's account. ${ }^{287}$ After acknowledging in passing the role of rehabilitation and service in the Wyman analysis, the Whitburn court simply moves on:

In Wyman, the Supreme Court held that the home visit at issue in that case was justified because of the important state interests furthered by the home visit. Although some of [the Wyman] factors related to the caseworker's duty to ensure the health and safety of children receiving AFDC benefits, many of the considerations emphasized by the Court apply in this case. ${ }^{288}$

The court thereafter discusses only those Wyman factors that overlap with or "approximate"289 Milwaukee's policy, with a single exception. ${ }^{290}$ At the end of the opinion, the court acknowledges that one factor-relating to the provision of notice in advance of the home visit-is missing from Milwaukee's protocol. In response, the court states that the difference "represent[s] only one of the eleven factors Wyman enumerated as supporting its [reasonableness] conclusion .... The strength of the remaining ten factors leads us to conclude that home visits conducted pursuant to the County's current policy ... are reasonable."291 Of those ten remaining factors purportedly offering "strong" analytic support for the Seventh Circuit's conclusion, no less than four relate in whole or in part to the rehabilitative and service objectives of the Wyman visit ${ }^{292}$ - considerations that are irrelevant to Milwaukee's search policy.

283. Id. at 322-23 (factor nine).

284. Sanchez, 464 F.3d at $923-25$.

285. Id. at 923 ("Here, as in Wyman, the home visits serve the important governmental interests of verifying an applicant's eligibility for welfare benefits and preventing fraud.").

286. See id. at $923-25$.

287. S.L. v. Whitburn, 67 F.3d 1299, 1308-10 (7th Cir. 1995).

288. Id. at 1308.

289. Id. at 1308-10.

290. Id. at 1310.

291. Id.

292. See supra notes $281-83$ and accompanying text. 


\section{b. The Role of the Caseworker}

Central to Wyman's analysis of the rehabilitative and service dimensions of the challenged visits was the particular role played by social workers in carrying them out. Few considerations capture more concretely the difference between the programs at issue than the fact that social workers entered the homes in Wyman while lawenforcement fraud investigators or employees of a private investigative service enter the homes in Sanchez and Whitburn. Highlighting the distinction, Wyman isolated the caseworker's function as an independent factor supporting the reasonableness of the intrusion: "The visit is not one by police or uniformed authority. It is made by a caseworker of some training whose primary objective is, or should be, the welfare, not the prosecution, of the aid recipient for whom the worker has profound responsibility." ${ }^{, 93}$ The Wyman dissent, even as it pressed to analogize the home visit to a traditional criminal search, acknowledged the supportive function of the visiting social worker: "No one questions the motives of the dedicated welfare caseworker. Of course, caseworkers seek to be friends, but the point is that they are also required to be sleuths." 294

The Seventh Circuit's application of this factor to Milwaukee's search program reduces to the observation that "the visit at issue was not made by police or uniformed authority." ${ }^{295}$ Having erased the Court's emphasis on the caseworker's "training," "profound responsibility," and role as "a friend to one in need," the Seventh Circuit equates Milwaukee's private investigator with Wyman's social worker based on the clothes they wear. ${ }^{296}$ The Ninth Circuit's approach is no less facile. As in Whitburn, the Sanchez majority recounts this factor without reference to the supportive functions of the visiting caseworker, framing the question instead as whether the visitor wears a uniform and reports "evidence of criminal activity for potential prosecution."297 Asserting that San Diego's fraud investigators do neither-a highly questionable proposition, as noted above ${ }^{298}$ - the Ninth Circuit concludes that the distinction between social workers and law enforcement personnel is inconsequential. ${ }^{299}$

\section{c. The Burden of the Intrusion}

Another consideration highlighted by the Wyman Court was the fact that the challenged policy "minimize[d] any 'burden' upon the homeowner's right against unreasonable intrusion." ${ }^{, 300}$ Listing the qualities of the visit that reflected this minimal burden, the Court noted that the applicant received "written notice several days in advance of the intended home visit"; that the "date was specified"; that "[p]rivacy [was] emphasized"; and that "snooping in the home [was] forbidden."301 The Court

293. Wyman v. James, 400 U.S. 309, 322-23 (1971).

294. Id. at 339 (Marshall, J., dissenting).

295. Whitburn, 67 F.3d at 1309.

296. Id.

297. Sanchez v. County of San Diego, 464 F.3d 916, 923-24 (9th Cir. 2006).

298. See supra note 280 and accompanying text.

299. See supra note 280 and accompanying text.

300. Wyman v. James, 400 U.S. 309, 321 (1971) (factor six).

301. Id. at 320-21 (noting that Mrs. James's complaint "refers to no snooping" and 
characterized the program as "a gentle means, of limited extent and of practical and considerate application," to achieve the state's interests. ${ }^{302}$ Virtually all of these moderating influences are absent from the contemporary home-visit policies that have withstood constitutional challenge.

\section{i. Providing Notice}

None of the challenged programs provides any specific notice of the impending visit; at best, applicants are told that they will receive a visit at some point during a tenday interval, ${ }^{303}$ in contrast to Wyman's specification of the date itself. ${ }^{304}$ In the retelling, however, the distinction disappears: each of the courts translates the divergent practice into a reflection of, rather than departure from, the salutary practice in Wyman. Thus the California Court of Appeals, in upholding Los Angeles's homevisit program, asserts that the policy does not "impose a substantial intrusion into personal privacy" and "is consistent with the reasoning" in Wyman because, inter alia, "[e]ligibility workers must give notice that a home visit is planned within 10 days of the intake." ${ }^{305}$ The court in Sanchez, considering a protocol that provides no notice of the period within which the search will occur, makes the same assertion: "The Project $100 \%$ home visits ... have many of the same procedural safeguards that the Wyman Court found significant. Applicants are given notice that they will be subject to a mandatory home visit and visits generally occur only during normal business hours."306

The Seventh Circuit addresses the distinction with a slightly greater degree of candor. After noting that Mrs. James received various procedural accommodations, including "several days' advance notice of the intended home visit," 307 Whitburn initially asserts that "[w] hile not all these factors are present in this case, the County's current policy does approximate these features. Currently, the County gives the applicant notice that his home will be visited in the next 10 days." ${ }^{, 308}$ In contrast to the courts in Sanchez and Smith, however, the Seventh Circuit does not end its analysis with this suggestion of rough parity between specific notice and a ten-day window. It instead acknowledges that Milwaukee's notice protocol differs from the Wyman policy ${ }^{309}$ but excuses the distinction on two grounds: first, that it is not sufficiently

"describes no impolite or reprehensible conduct of any kind").

302. Id. at 319.

303. See, e.g., Sanchez v. County of San Diego, 464 F.3d 916, 919 (9th Cir. 2006) ("Applicants ... are not given notice of the exact date and time the visit will occur. The visits are generally made within 10 days of receipt of the application ...."), aff' $g$ No. 00CV1467JM(JFS), 2003 WL 25655642, at *2 (S.D. Cal. Mar. 10, 2003) ("Applicants . . are not informed that the visit will occur ... within ten days of the application being submitted."); S.L. v. Whitburn, 67 F.3d 1299, 1310 (7th Cir. 1995) (ten-day window); Smith v. L.A. County Bd. of Supervisors, 128 Cal. Rptr. 2d 700, 712 (Ct. App. 2002) (ten-day window).

304. Wyman, 400 U.S. at 320-21. The Court in Wyman noted evidence in the record suggesting that, in practice, caseworkers often made unannounced visits. The Court thereafter ignored the evidence and analyzed the policy as written rather than as applied. See id. at 320 n.8.

305. Smith, 128 Cal. Rptr. $2 d$ at 712.

306. Sanchez, 464 F.3d at 924 (citation omitted).

307. Whitburn, 67 F.3d at 1309.

308. Id.

309. Id. at 1310. 
important to outweigh the other purported similarities between the two programs, ${ }^{310}$ and, second, that the specific notice provided in Wyman is actually a bad idea. ${ }^{311}$

The reasonableness of this policy is underscored when one considers the practical limitations for the County as well as the applicant on providing notice of the specific day of the visit. ... [O]ften applicants are not there on the day the County attempts to conduct the home visit. Or the County worker may be unable to complete all of the scheduled home visits because others set for that day take longer than expected. Under a requirement that notice of the specific day be given, new notice-even for a visit the following day-would be required. Not only would this prove to be expensive and burdensome to the County, but in the end the applicant could be the one to suffer, either by being required to be at home for the scheduled visit, or by a delay in the verification process and a corresponding delay in receiving benefits. ${ }^{312}$

Apart from its incoherent factual premise, ${ }^{313}$ this critique is remarkable in two respects. First, it applies with equal or greater force to Milwaukee's own protocol, unless one presumes that aid recipients are sufficiently desperate for assistance that they will suspend all life activities outside the home for the ten-day period and wait patiently for a knock at the door. If that is true - and it well may be b $^{314}$ - the magnitude of the burden imposed on aid applicants by Milwaukee's procedure dwarfs any of the purported benefits identified in the Seventh Circuit's analysis. Otherwise, applicants with no idea when a visit might occur may well be gone when the investigator arrives, necessitating a second or third visit that triggers precisely the same delays and burdens that supposedly so trouble the Whitburn court. The proposition that a surprise visit is better for aid applicants than a scheduled one is nearly fatuous - not merely with respect to the court's claim that a surprise visit might accelerate the time within which applicants obtain aid, ${ }^{315}$ but more basically with respect to its humiliating and disruptive impact on the applicant's life. Without the ability to anticipate a visit, applicants lose all control over the circumstances under which strangers may enter their homes and face instead the indignity of their lives laid bare at a moment's notice.

Second, the Seventh Circuit offers this critique in defiance of Wyman's own resolution of precisely the same question. Every alleged drawback of specific notice

310. Id.

311. Id.

312. Id.

313. The court asserts that specific notice would delay the receipt of benefits. The argument rests in part on the proposition that "applicants [often] are not there on the day the County attempts to conduct the home visit," thus necessitating follow-up visits that might be delayed if the County were forced to issue new notice. $I d$. What the analysis inexplicably omits to acknowledge is the obvious fact that applicants would be at home for the initial visit if they received specific notice of it in the first instance-rendering irrelevant the court's purported concem about the timing of subsequent follow-up efforts.

314. Knowing that vital aid to feed one's family is dependent on a satisfactory home visit, applicants facing an open window of time may well suspend much of their life's activitiesincluding, notably, efforts to find and maintain employment-so that they do not risk the denial of aid for failure to comply with the search condition.

315. See supra note 313. 
identified by the Seventh Circuit applies with equal force to the procedure lauded in Wyman as an element of Fourth Amendment reasonableness. There, as here, caseworkers may be running late, may be forced to reschedule, and may delay verification until the visit occurs-but the Supreme Court nevertheless concluded that the obvious benefits of specific notice still predominated. ${ }^{316}$ The Seventh Circuit's argument amounts to a declaration that the Supreme Court got it wrong and should be ignored.

Unacknowledged in all of these decisions is the evident reason why the challenged investigatory policies provide no notice. If the premise of the programs is to detect fraud or ineligibility - often in the form of an undeclared male in the household-the element of surprise will play an important role in uncovering the stray toothbrush, or pair of men's shoes, that might betray his presence. The fact that Wyman's program lacked this essential investigatory attribute highlights the fundamentally different procedure under review in that case and the contrasting focus of contemporary search programs-a focus that is exclusively investigatory and thus squarely within the reach of traditional Fourth Amendment analysis. The specific notice provided in Wyman, which advanced the objectives of a largely rehabilitative and respectful social-worker visit, is irreconcilable with any policy designed to catch unsuspecting applicants in disqualifying conduct.

\section{ii. No "Snooping"}

While Wyman provided little description of the activities of the social worker within the home, the Court strongly suggested that the visit did not include an invasive search. In describing the objections of Mrs. James, the Court noted that she supported her claim with affidavits from other aid recipients who complained about various aspects of their home visits. ${ }^{317}$ As described in the opinion, the complaints of Mrs. James and her corroborating witnesses made no reference to any search practices but instead focused on the nature of the colloquy between recipients and their social workers - for example, several complained that the caseworkers asked embarrassing questions in the presence of children. ${ }^{318}$

[Mrs. James] alleges only ... that on previous visits and, on information and belief, on visitation at the home of other aid recipients, "questions concerning personal relationships, beliefs and behavior are raised and pressed which are unnecessary for a determination of continuing eligibility." Paradoxically, this same complaint could be made of a conference held elsewhere than in the home .... The same complaint could be made of the census taker's questions. ${ }^{319}$

Corroborating the conclusion that the challenged visit focused on a discussion with the recipient rather than an inspection of her home, the Court twice observed that the reasonableness of the policy was bolstered by the fact that it involved no

316. See supra notes $300-02$ and accompanying text.

317. Wyman v. James, 400 U.S. 309,320 n.8 (1971).

318. Id.

319. Id. at 321 . 
"snooping." 320 Although "snooping" is hardly a term of art, its definition centers on the act of "prowl[ing] or pry[ing]"321 and necessarily implies some significant scrutiny of private areas and effects.

The search policies implemented by the counties of San Diego and Milwaukee are unlimited in reach, permitting investigators to inspect any closed or private space within the home, while the policy of Los Angeles County involves a more limited walk-through that does not include inspection of drawers, closets, and other closed spaces. ${ }^{322}$ All three reach well beyond the in-home questioning evidently at issue in Wyman. Of the opinions upholding these practices, however, only one acknowledges the distinction. ${ }^{323}$ The Ninth Circuit in Sanchez dismissed the "snooping" factor in a footnote with the assertion that, "[s]ince the investigators have legitimate verificationrelated reasons for viewing ... items [in closets, drawers, or medicine cabinets], and only do so with the homeowner's explicit consent, their activity cannot fairly be characterized as "snooping.",324

The Ninth Circuit's argument grafts a novel distinction between legitimate and illegitimate investigatory activities onto the concept of "snooping." The definition of the word-which focuses on the act of "pry[ing] into the private affairs of others" ${ }^{\text {"325 }}$ does not require such a limitation, and there is no indication in Wyman that the Court had such a distinction in mind when it emphasized the limited reach of the social worker's intrusion. Indeed, under the Ninth Circuit's reasoning, an invasive search would have been entirely "legitimate" on the facts of Wyman itself, since the social worker was charged in part with verifying "that the intended and proper objects of that tax-produced assistance are the ones who benefit from the aid it dispenses." virtually any space or object within the home might yield information bearing on the

320. Id.

321. WeBster's Universal COLLEGE Dictionary 743 (2001).

322. See supra notes $227-34,247,253-54$ and accompanying text.

323. See Sanchez v. County of San Diego, 464 F.3d 916, 924 n.13 (9th Cir. 2006) (rejecting the argument that San Diego's more intrusive search practices conflict with Wyman's admonition against "snooping"). In Smith, the California Court of Appeal contrasted Los Angeles's program instead with a mass welfare raid at issue in an earlier California case:

In Parrish [v. Civil Service Commission, 425 P.2d 223 (Cal. 1967)], the social workers were instructed to "conduct a thorough search of the entire dwelling, giving particular attention to beds, closets, bathrooms and other possible places of concealment." In contrast, the pilot program here did not involve mass raids .... Eligibility workers making a home visit are instructed not to open closets or drawers.

Smith v. L.A. County Bd. of Supervisors, 128 Cal. Rptr. 2d 700, $713-14$ (Ct. App. 2002).

324. Sanchez, 464 F.3d. at 924 n. 13 (emphasis in original). As to the assertion that consent might transform an invasive search into something other than "snooping," the Sanchez dissent provides a succinct response: "[O]btaining consent to snoop cannot change the nature of the ensuing conduct-snooping - any more than obtaining consent to search changes the nature of the search that follows." Id. at 936 (Fisher, J., dissenting) (emphasis in original). Moreover, the majority's argument rests on the presence of valid consent and is thus irrelevant in this context, given the highly coercive nature of the circumstances surrounding an applicant's request for subsistence aid. See supra notes 107, 257.

325. THE AMERICAN HERTTAGE Dictionary OF THE ENGLISH LANGUAGE 1647 (2000).

326. Wyman v. James, 400 U.S. 309, 319 (1971). 
"objects of ... assistance," no area would fall beyond the "legitimate" reach of a verification-related inspection. Accordingly, if the Court in Wyman used "snooping" in the manner suggested by the Ninth Circuit, it necessarily extolled not simply the absence of an invasive inspection of Mrs. James's home but more precisely the absence of an improperly motivated search of the premises.

The only activity that might run afoul of a "snooping" proscription, so construed, would be rummaging about the recipient's house for information wholly unrelated to the verification objectives of the home visit-perhaps to satisfy the caseworker's private curiosity or the government's interest in using the home visit as a pretense to spy on its citizenry. ${ }^{327}$ It defies any plausible reading of the text to suggest that the Wyman Court, in highlighting the absence of "snooping" in the visits at issue, was merely lauding the fact that the social workers resisted such an improbable temptation-rather than emphasizing instead the singular fact that the visits at issue involved no inspection whatsoever, despite the "legitimate" investigatory value of a more invasive search.

\section{d. Summary}

Shorn of its rehabilitative purpose, the participation of trained and supportive social workers, the provision of advance notice, and virtually all limits on its invasive reach, the reinvented Wyman home visit is a frankly confrontational and highly intrusive encounter between applicants and investigators. The Wyman factors left intact by the contemporary caricature of its analysis-the need to assure that public funds are properly spent, ${ }^{328}$ the importance of verifying eligibility, ${ }^{329}$ and the diminished privacy interests of those seeking public aid ${ }^{330}$-justify exceptionally aggressive investigative techniques that bear no relation to the actual visits upheld in the case. As seven judges noted in their dissent from the Ninth Circuit's denial of rehearing en banc in Sanchez, "The differences between San Diego's program and the program in Wyman are of a quality and character that cannot be ignored. ... [T] he simple fact of the matter is that a home visit in Sanchez is fundamentally different from a home visit in Wyman."331 Rather than admit the obvious divergence, the courts in Sanchez, Whitburn, and Smith have instead manufactured a fictionalized version of the precedent to support-indeed, to dictate - their authorization of dramatically more aggressive home search programs.

\section{Reinventing Special Needs}

The second rationale employed to justify aggressive home search policies focuses on the Fourth Amendment's special-needs doctrine that emerged in the decades following Wyman. Among the reasons why Wyman is-or should be-irrelevant to the current analysis of search practices is the fact that the doctrinal approach to the

327. Cf. Sanchez, 464 F.3d at 924 n. 13 .

328. Wyman, 400 U.S. at 318-19.

329. Id. at 322 .

330. Id. at 319.

331. Sanchez v. County of San Diego, 483 F.3d 965, 967 (9th Cir. 2007) (Pregerson, J., dissenting from the denial of rehearing en banc). 
question presented in Wyman has changed dramatically in the intervening years. ${ }^{332}$ The new doctrine, originating in decisions that predated Wyman but more fully articulated in a series of cases decided in the late 1980s and 1990s, specifically addresses the permissibility of warrantless and suspicionless searches for purposes unrelated to law enforcement. ${ }^{333}$ Despite the fact that the search procedures at issue in cases such as Sanchez and Whitburn lack virtually all the essential attributes of the narrow class of suspicionless inspections sanctioned by the new methodology, courts have nonetheless construed the special-needs doctrine to accommodate the challenged practices-again, by seriously distorting the governing precedent. ${ }^{334}$

\section{a. Analytic Framework}

With its decision in Camara v. Municipal Court ${ }^{335}$ in 1967, the Supreme Court set in motion a distinct jurisprudence to assess noncriminal searches under the Fourth Amendment. The Camara Court held that the Fourth Amendment's traditional warrant requirement applied to administrative searches, such as housing inspections, but that the corresponding requirement of probable cause was inapplicable in view of the noncriminal interests at stake. ${ }^{336}$ Wyman, which followed Camara by five years, ignored its holding and engaged in a sui generis analysis of the noncriminal, warrantless entry at issue in the case-rendering the opinion anomalous even by thenapplicable constitutional standards. ${ }^{337}$ That divergence has only widened over the intervening years as the Court has further refined the application of the Fourth Amendment in the noncriminal context with the development of the special-needs doctrine. $^{338}$

In Skinner v. Railway Labor Executives' Association, ${ }^{339}$ the Supreme Court described the core principles of its new methodology:

[T] he permissibility of a particular practice "is judged by balancing its intrusion on the individual's Fourth Amendment interests against its promotion of legitimate governmental interests."

In most criminal cases, we strike this balance in favor of the procedures described by the Warrant Clause of the Fourth Amendment. Except in certain welldefined circumstances, a search or seizure in such a case is not reasonable unless it is accomplished pursuant to a judicial warrant issued upon probable cause. We have recognized exceptions to this rule, however, "when 'special needs, beyond the normal need for law enforcement, make the warrant and probable-cause requirement impracticable." When faced with such special needs, we have not

332. See, e.g., Sanchez, 464 F.3d at 922 n.8.

333. See generally Jennifer Y. Buffaloe, Note, "Special Needs" and the Fourth Amendment: An Exception Poised to Swallow the Warrant Preference Rule, 32 HARV.C.R.-C.L.L. REV. 529 (1997).

334. See infra notes $348-401$ and accompanying text.

335. 387 U.S. 523 (1967).

336. Id. at $532-34,538-39$.

337. See, e.g., 2 LAFAVE ET AL., supra note 120, $\$ 3.9(\mathrm{~d})$.

338. See, e.g., infra notes 369-71 and accompanying text.

339. 489 U.S. 602 (1989). 
hesitated to balance the governmental and privacy interests to assess the practicality of the warrant and probable-cause requirements in the particular context. $^{340}$

Central to the special-needs analysis, then, is balancing the privacy interests at stake against the strength of the countervailing government interest in conducting a search outside the constraints of the Warrant Clause. In striking this balance, the Court has moved beyond its holding in Camara to uphold warrantless and suspicionless drug testing of railroad employees involved in train accidents, ${ }^{341}$ government agents involved in drug interdiction efforts, ${ }^{342}$ and public school students engaged in athletics $^{343}$ and other extracurricular activities. ${ }^{344}$ The Court has also upheld warrantless and suspicionless home searches conducted as a condition of probation ${ }^{345}$ but has struck down programs requiring drug testing of candidates for state office $\mathrm{e}^{346}$ and maternity patients in a public hospital. ${ }^{347}$ While these authorities represent a significant expansion of the state's power to conduct searches outside the traditional requirements of a warrant and probable cause, the scope of the doctrine is nonetheless limited in ways that evidently exclude the aggressive practices at issue in contemporary welfare search cases.

\section{b. A Uniquely Pedestrian "Special Need"}

The special-needs calculation turns initially on the presence of a governmental interest that is sufficiently substantial to justify the suspension of otherwise applicable Fourth Amendment protections. ${ }^{348}$ In the absence of such a "special need," the analysis goes no further. ${ }^{349}$ While the Court has made "little or no effort . . . to explain what these 'special needs' are,"350 inviting criticism that the term is "no more than a label that indicates when a lax standard will apply," 351 the practical application of the

340. Id. at 619 (quoting Delaware v. Prouse, 440 U.S. 648, 654 (1979); Griffin v. Wisconsin, 483 U.S. 868, 873 (1987)) (citations omitted).

341. Id. at 618-33.

342. Nat'l Treasury Employees Union v. Von Raab, 489 U.S. 656, 666-77 (1989).

343. Vernonia Sch. Dist. 47J v. Acton, 515 U.S. 646, 652-66 (1995).

344. Bd. of Educ. v. Earls, 536 U.S. 822, 828-38 (2002) (upholding mandatory drug testing for all students participating in competitive extracurricular activities).

345. Griffin v. Wisconsin, 483 U.S. 868, 872-80 (1987).

346. Chandler v. Miller, 520 U.S. 305, 313-23 (1997).

347. Ferguson v. City of Charleston, 532 U.S. 67, 76-86 (2001).

348. Chandler, 520 U.S. at 318 (stating that a special need "must be substantial-important enough to override the individual's acknowledged privacy interest [and] sufficiently vital to suppress the Fourth Amendment's normal requirement of individualized suspicion").

349. Id.; see, e.g., 19 Solid Waste Dep't Mechs. v. City of Albuquerque, 156 F.3d 1068, 1072 (10th Cir. 1998).

350. William J. Stuntz, Implicit Bargains, Government Power, and the Fourth Amendment, 44 STAN. L. REV. 553, 554 (1992).

351. Id.; see also Tracey Maclin, Is Obtaining an Arrestee's DNA a Valid Special Needs Search Under the Fourth Amendment? What Should (and Will) the Supreme Court Do?, 34 J.L. MED. \& ETHICS 165, 170 (2006). 
doctrine has been limited to two relatively discrete sets of circumstances. ${ }^{352}$ At least in the estimation of the Court itself, these circumstances constitute a "closely guarded category of constitutionally permissible suspicionless searches."

First, the Court has utilized the special-needs doctrine to justify suspicionless search practices that purport to promote public safety. Cases involving this form of governmental interest include decisions upholding suspicionless drug testing of railroad employees and customs agents as well as suspicionless home searches of probationers. ${ }^{354}$ In striking down a drug-testing program directed at candidates for public office, the Court focused on the absence of any credible public-safety objective as pivotal to its conclusion: "[W] here, as in this case, public safety is not genuinely in jeopardy, the Fourth Amendment precludes the suspicionless search, no matter how conveniently arranged." 355

Second, and relatedly, the Court has applied the special-needs doctrine when the state purports to act in loco parentis to protect the health and safety of public schoolchildren under its supervision. ${ }^{356}$ In Vernonia School District 47Jv. Acton and Board of Education v. Earls, the Court upheld broad, suspicionless drug-testing programs of public school students on the dual grounds that drug abuse poses a substantial public health risk and that the state is uniquely empowered in its role as guardian of schoolchildren to act outside the normal constraints of the Fourth Amendment. ${ }^{357}$ As Justice Scalia noted in Vernonia,

We caution against the assumption that suspicionless drug testing will readily pass constitutional muster in other contexts. The most significant element in this case is the first we discussed: that the Policy was undertaken in furtherance of the government's responsibilities, under a public school system, as guardian and tutor of children entrusted to its care. ${ }^{358}$

352. See infra notes $354-58$ and accompanying text.

353. Chandler, 520 U.S. at 309.

354. See Skinner v. Ry. Labor Executives' Ass'n, 489 U.S. 602, 634 (1989) (referring to "surpassing safety interests"); Nat'l Treasury Employees Union v. Von Raab, 489 U.S. 656, 674 (1989) (referring to "extraordinary safety and national security hazards"); Griffin v. Wisconsin, 483 U.S. 868, 875 (1987) (referring to the community's safety from harm by the "probationer's being at large").

355. Chandler, 520 U.S. at 323; see, e.g., Bd. of Educ. v. Earls, 536 U.S. 822, 836-37 (2002).

356. Earls, 536 U.S. at 836-37; Vernonia Sch. Dist. 47 J v. Acton, 515 U.S. $646,654-57$ (1995); cf. New Jersey v. T.L.O., 469 U.S. 325, 351-53 (1985) (Blackmun, J., concurring).

357. Earls, 536 U.S. at 829-30; Vernonia, 515 U.S. at 654-55.

358. 515 U.S. at 665 . In addition to these two primary areas of application, the special-needs doctrine and related variants have been employed to uphold warrantless and suspicionless searches for purposes of conducting drunk-driving and immigration inspections at automobile checkpoints, Mich. Dep't of State Police v. Sitz, 496 U.S. 444, 448-55 (1990), United States v. Martinez-Fuerte, 428 U.S. 543, 556-67 (1976), and to investigate potential employee misconduct within a government workplace, O'Connor v. Ortega, 480 U.S. 709, 725-26 (1987) (plurality opinion). Notably, the Court has limited the application of the doctrine in the context of automobile checkpoints to the detection of actively intoxicated drivers and barred its application in circumstances where the police search instead for potential intoxicants not yet 
The welfare searches at issue here are not related to either the state's interest in public safety or its special responsibility to schoolchildren in its custody and care. They are instead expressly designed to advance a need that is not special in any relevant respect: the government's mundane administrative interest in the fiscal integrity of a benefits program..$^{359}$ While the scope of the special-needs doctrine is subject to considerable confusion, ${ }^{360}$ no credible characterization of its existing reach supports the proposition that an interest "so generalized and ever-present" ${ }^{\text {"361 }}$ would be sufficient, standing alone, to trigger its application. To the contrary, as the Court underscored in Chandler v. Miller, ${ }^{362}$ the requisite need must be "sufficiently vital to suppress the Fourth Amendment's normal requirement of individualized suspicion."363

Evidently recognizing that the interest at stake bears no relation to the class of special needs supporting suspicionless searches, the courts in Sanchez, Whitburn, and Smith simply ignore the content of the doctrine. The court in Smith thus declares without citation that " $[t]$ he governmental interest in reducing welfare fraud is great" and concludes on that basis that a sufficiently compelling interest is present. ${ }^{364}$ Taking a different approach, the district court in Sanchez fills the analytic gap by conflating its special-needs analysis with the irreconcilable reasoning of Wyman. ${ }^{365}$ Citing Wyman for the proposition that the government "has appropriate and paramount interest and concern in seeing and assuring that the intended and proper objects of ... [welfare] assistance are the ones who benefit from the aid it dispenses," 366 the court concludes as a "consequen[ce]" that San Diego County "has a 'special need' in ensuring that scarce public resources, intended for the benefit of needy children, are not wrongly consumed by those ineligible for such aid." ${ }^{237}$ The Seventh Circuit in Whitburn makes the identical argument. ${ }^{368}$ Wyman, however, is not a reflection of the special-needs

consumed: "Only with respect to a smaller class of offenses, however, is society confronted with the type of immediate, vehicle-bound threat to life and limb that the sobriety checkpoint in Sitz was designed to eliminate." City of Indianapolis v. Edmond, 531 U.S. 32, 43 (2000).

359. See, e.g., Sanchez v. County of San Diego, 483 F.3d 965, 968 (9th Cir. 2007) (Pregerson, J., dissenting from denial of en banc review) (describing the state's "general interest" in preventing fraud).

360. Maclin, supra note 351, at 170.

361. Edmond, 531 U.S. at 44.

362. 520 U.S. 305 (1997).

363. Id. at 318; see also Maclin, supra note 351, at 176 ("Chandler appears to have 'raised the bar' on the threshold requirement for a special needs search.").

364. Smith v. L.A. County Bd. of Supervisors, 128 Cal. Rptr. 2d 700, 712 (Ct. App. 2002).

365. See infra notes 369-71 and accompanying text.

366. Sanchez v. County of San Diego, No. 00CV1467JM(JFS), 2003 WL 25655642, at *6 (S.D. Cal. Mar. 10, 2003) (quoting Wyman v. James, 400 U.S. 309, 318-19 (1971)) (emphasis omitted). Wyman's actual analysis of the government's rationale involves consideration of a variety of additional factors that the Sanchez court ignores. See supra notes 260-331 and accompanying text.

367. Sanchez, 2003 WL 25655642, at *6. The Ninth Circuit affirmed the holding on grounds that "the underlying purpose of the home visits is to verify eligibility ... and not for general law enforcement purposes," Sanchez v. County of San Diego, 464 F.3d 916, 926 (9th Cir. 2006), thus expanding the special-needs doctrine to include all searches conducted for purposes unrelated to law enforcement-in defiance of Chandler's holding and admonition, supra notes 353-63 and accompanying text, which the Sanchez majority ignored.

368. See S.L. v. Whitburn, 67 F.3d 1299, 1310 (7th Cir. 1995)(relying on the same language 
doctrine but instead a departure from it. ${ }^{369}$ In particular, the government rationale recognized in Wyman as supporting the reasonableness of the home visit is irreconcilable with the interests that the Court has subsequently found to justify a special-needs search. ${ }^{370}$ By grafting Wyman's inapposite reasoning upon the specialneeds analysis, the courts in Sanchez and Whitburn manufacture a rationale for the challenged searches that defies the governing doctrine. ${ }^{371}$

\section{c. A Uniquely Compelling Privacy Interest}

After considering the strength of the government's rationale, the special-needs inquiry next weighs the countervailing privacy interest. ${ }^{372}$ The privacy interest at issue here is "the sanctity of private dwellings, ordinarily afforded the most stringent Fourth Amendment protection., "373 Authorities are legion supporting the proposition that "the unambiguous physical dimensions of an individual's home"374 define the "zenith" of constitutionally protected zones of privacy. ${ }^{375}$ As the Court recently noted, "We have

in Wyman to uphold Milwaukee's home-search program).

369. See, e.g., Sanchez v. County of San Diego, 483 F.3d 965, 966 (9th Cir. 2007) (Pregerson, J., dissenting from the denial of en banc review) ("[A]llowing Wyman to constrict the bounds of our Fourth Amendment jurisprudence ignores over thirty-five years of intervening law."); Michael D. Socha, An Analysis of Michigan's Plan for Suspicionless Drug Testing of Welfare Recipients Under the Fourth Amendment "Special Needs" Exception, 47 WAYNE L. REV. 1099, 1117 (2001) ("Wyman is a case decided in 1971, eighteen years before Skinner and Von Raab ... . The Supreme Court developed a separate and distinct line of reasoning and precedent for dealing with blanket, suspicionless drug testing subsequent to Wyman.").

370. See supra notes 354-63 and accompanying text; see also Marchwinski v. Howard, 113 F. Supp. 2d 1134, 1143 (E.D. Mich. 2000) ("To the extent that Wyman could be construed as allowing [searches outside the scope of the discussion in Chandler], its holding is no longer viable."), rev'd, 309 F.3d 330 (6th Cir. 2002), vacated by an equally divided en banc court, 60 F. App'x 601 (6th Cir. 2003). Moreover, the Wyman rationale relied upon by the Sanchez and Whitburn courts was only one of several-including, notably, rehabilitation-that the Court considered in combination to reach its reasonableness conclusion. See supra notes 262-331 and accompanying text. The absence of those other moderating objectives suggests that, even under Wyman, the referenced rationale would be insufficient to independently establish the reasonableness of contemporary search programs.

371. Cf. Marchwinski, 113 F. Supp. 2d at 1143 ("Even if Wyman did support [suspicionless drug testing of welfare recipients], it would not be sustainable in light of the more recent Chandler [decision].").

372. Almost all of the major special-needs cases have addressed some form of suspicionless drug testing. See Bd. of Educ. v. Earls, 536 U.S. 822, 826-27 (2002); Ferguson v. City of Charleston, 532 U.S. 67, 70-73 (2001); Chandler v. Miller, 520 U.S. 305, 309-10 (1997); Vernonia Sch. Dist. 47J v. Acton, 515 U.S. 646, 650-51 (1995); Skinner v. Ry. Labor Executives' Ass'n, 489 U.S. 602, 608-12 (1989); Nat'l Treasury Employees Union v. Von Raab, 489 U.S. 656, 660-63 (1989). In assessing the gravity of these intrusions, the Court has focused on the particular methods employed in the testing programs and the degree to which the subjects are assured privacy in providing test samples. See Earls, 536 U.S. at 830-32; Ferguson, 532 U.S. at 78; Chandler, 520 U.S. at 318; Vernonia, 515 U.S. at 658-60; Skinner, 489 U.S. at 626-27; Von Raab, 489 U.S. at 671-72.

373. United States v. Martinez-Fuerte, 428 U.S. 543, 561 (1976).

374. Payton v. New York, 445 U.S. 573, 589 (1980).

375. Sanchez v. County of San Diego, 483 F.3d 965, 968 (9th Cir. 2007) (Pregerson, J., 
.. . lived our whole national history with an understanding of 'the ancient adage that a man's house is his castle . ...",376 The state's corresponding obligation to respect the home's "well-being, tranquility, and privacy" is an interest "of the highest order in a free and civilized society.,"377

Contemporary welfare search practices entail highly intrusive inspections of the most intimate and private spaces within an applicant's home. ${ }^{378}$ In some programs, the scope of the inspection is committed to the discretion of the investigator and is thus unlimited in any articulated respect. ${ }^{379}$ In view of the highly protected status of the home, the severity of the potential intrusion upon it, and the pedestrian nature of the government's general interest in confirming eligibility for a public-benefits program, it strains credulity to suggest that the special-needs calculation might possibly permit such practices.

This conclusion is bolstered by the single case in which the Court has upheld a special-needs home search. ${ }^{380}$ In Griffin $v$. Wisconsin, ${ }^{381}$ the Court ruled that the state could condition probation upon a requirement that officers be allowed to conduct warrantless searches of a probationer's home if "reasonable grounds" exist to suspect the presence of contraband. ${ }^{382}$ The Court acknowledged that "[a] probationer's home, like anyone else's, is protected by the Fourth Amendment[],"383 but that probationers have a significantly diminished expectation of privacy based on their highly supervised status. ${ }^{384}$ The Court stressed that probationers "do not enjoy 'the absolute liberty to which every citizen is entitled, but only ... conditional liberty properly dependent on observance of special [probation] restrictions." ${ }^{385}$ As the Court later explained, "the legitimacy of certain privacy expectations vis-à-vis the State may depend upon the individual's legal relationship with the State." ${ }^{386}$ Elaborating on this principle, lower courts have permitted special-needs searches of parolees' homes ${ }^{387}$ but have prohibited warrantless home searches as a condition of release for pretrial detainees, ${ }^{388}$ stressing

dissenting from denial of en banc rehearing); see supra text accompanying notes 34-38.

376. Georgia v. Randolph, 547 U.S. 103, 115 (2006) (quoting Miller v. United States, 357 U.S. 301, 307 (1958)).

377. Carey v. Brown, 447 U.S. 455, 471 (1980).

378. See supra notes $227-34,247$ and accompanying text.

379. See, e.g., Sanchez v. County of San Diego, No. 00CV1467JM(JFS), 2003 WL 25655642, at *8 n.8 (S.D. Cal. Mar. 10, 2003), aff d, 464 F.3d 916 (9th Cir. 2006); cf. Smith v. L.A. County Bd. of Supervisors, 128 Cal. Rptr. 2d 700, 704 (Ct. App. 2002) (scope of search is limited).

380. Sanchez v. County of San Diego, 464 F.3d 916, 940 n.11 (9th Cir. 2006) (Fisher, J., dissenting) ("Griffin appears to be the only case in which 'special needs' permitted a warrantless entry and search of anyone's home.").

381. 483 U.S. 868 (1987).

382. Id. at $872-73$.

383. Id. at 873 .

384. Id. at 874-75.

385. Id. at 874 (quoting Morrissey v. Brewer, 408 U.S. 471, 480 (1972)) (alterations in original).

386. Vernonia Sch. Dist. 47J v. Acton, 515 U.S. 646, 654 (1995).

387. See, e.g., United States v. Trujillo, 404 F.3d 1238, 1241-44 (10th Cir. 2005); United

States v. Lewis, 71 F.3d 358, 361-62 (10th Cir. 1995).

388. See United States v. Scott, 450 F.3d 863, 871 (9th Cir. 2005). 
that "pretrial releasees are ordinary people who have been accused of a crime but are presumed innocent." 389

The contrast between the privacy expectation in Griffin and the interest at stake in contemporary welfare searches is apparent. In Griffin, the authorized search-based, notably, on reasonable suspicion-targeted the home of a convicted felon under the continuing supervision of the state penal authority. ${ }^{390}$ In contrast, the challenged welfare inspections target the homes of individuals who have committed no crime, present no threat to public safety, and have no special "legal relationship" with the state apart from their commonplace status as applicants for a public benefit. ${ }^{391}$ As Judge Fisher noted in his Sanchez dissent, "unlike convicted felons, welfare applicants have no lesser expectation of privacy in their homes than the rest of us.... [Applicants] have committed no wrong and [the welfare authorities] have all but disclaimed any rehabilitative or supervisory purpose. ${ }^{, 392}$ The distinction is especially conspicuous in light of the fact that the Ninth Circuit has elsewhere refused to permit pretrial searches of the homes of the criminally accused on grounds that they "have suffered no judicial abridgment of their constitutional rights." 393 As Judge Fisher observed, Sanchez thus establishes that "those in need of public assistance to provide food, shelter and medical care for themselves and their families have less protection under the Fourth Amendment than those charged with a crime."394

In defending the improbable assertion that the challenged searches implicate an insubstantial privacy expectation, the courts in Sanchez, Whitburn, and Smith resort again to the inapposite authority of Wyman and to distortions of the controlling doctrine. Citing Griffin for the general proposition that "a person's relationship with the state can reduce that person's expectation of privacy even within the sanctity of the home ${ }^{395}$ - yet ignoring Griffin's radically different facts and analysis ${ }^{396}$ - the Ninth Circuit in Sanchez cursorily asserts that "it is reasonable for welfare applicants who desire direct cash governmental aid to undergo eligibility verification through home visits." ${ }^{397}$ Citing Wyman, the court in Whitburn declares that welfare applicants necessarily must have a diminished privacy expectation in view of the benefits they

389. Id. at 871 .

390. Griffin, 483 U.S. at 874-75.

391. Sanchez v. County of San Diego, 464 F.3d 916, 941 (9th Cir. 2006) (Fisher, J., dissenting) ("With the exception of convicted felons, neither we nor the Supreme Court has ever held that an individual's privacy expectation in the home was reduced to a level of unreasonableness as a result of their relationship with the state.").

392. Id. at 940 .

393. Scott, 450 F.3d at 872 .

394. Sanchez, 464 F.3d at 944 (Fisher, J., dissenting).

395. Id. at 927.

396. See supra notes 382-85 and accompanying text; $c f$. Sanchez v. County of San Diego, 483 F.3d 965, 969 (9th Cir. 2007) (Pregerson, J., dissenting from denial of en banc rehearing) ("Comparison to Wyman and the more recent line of special needs cases reveals the utterly unreasonable nature of this search program. The facts of Sanchez place the panel majority's ruling in new and untenable territory."').

397. Sanchez, 464 F.3d at 927; see also Sanchez v. County of San Diego, No. 00CV1467JM(JFS), 2003 WL 25655642, at *7 (S.D. Cal. Mar. 10, 2003). The Sanchez court also argues that the searches are consensual and thus even less invasive of privacy. The assertion is in considerable tension with the facts. See supra notes 107, 257. 
seek to obtain. ${ }^{398}$ The court in Smith, also in reliance on Wyman, similarly concludes that "the home visit program [does not] impose a substantial intrusion into personal privacy.",399

The difference between aid applicants and convicted criminals is hardly elusive. The contrary assertion-that a request for public benefits triggers a sufficiently debasing legal relationship with the state to open medicine cabinets and dresser drawers for a suspicionless special-needs inspection-is inimical to any tenable characterization of the law. ${ }^{400}$ As one recent commentary noted, "Every citizen is in a 'relationship' with the government, and fraud abounds in all governmental programs. What will distinguish this case from the case in which investigators want to rummage through drawers in citizens' homes to 'prevent' tax fraud?" ${ }^{401}$ The answer, evidently, is the relative wealth of those seeking the Fourth Amendment's protections.

\section{Making Sense of Nonsense: The Poor as a Subconstitutional Class}

I mean, you walk in and you see the $\$ 5000$ widescreen $T V$, and the person says, "oh, I have all this trouble supporting my children 'cause I don't have a man to help mc in the house, "and there's obviously a man to help her in the house-and that's seeing if the charity is going where it's supposed to go. ... And you open a closet and you see four suits... and the golf clubs of the person that doesn't live there, supposedly—same thing, isn't it? ? $^{02}$

- Judge Andrew Kleinfeld, Ninth Circuit Court of Appeals, during oral argument in Sanchez v. County of San Diego

When a federal judge adjudicating the privacy rights of aid applicants suggests that the question plausibly turns on the prospect of welfare recipients cashing government checks to help cover the cost of greens fees, business attire, and in-home theatre systems, the reality of judicial bias is apparent. Judge Kleinfeld's remarks during oral argument in Sanchez betray a conception of the poor that is so incuriously skewed as to nearly defy apprehension-a world of golfing swindlers who fund their luxurious lifestyle by misappropriating the charity of hard-working taxpayers. It is a conception of the poor, however, that is as time-honored in American discourse as it is distorted.

The contemporary authorities sustaining aggressive welfare search practices must be understood against this perceptual backdrop. The holdings, like the torturous reasoning required to reach them, are so hostile to traditional Fourth Amendment doctrine that they cannot fairly be understood as its product. The outcomes instead suggest that the law actually matters little: the poor, presumptively different, inhabit their own

398. S.L. v. Whitburn, 67 F.3d 1299, 1310 (7th Cir. 1995).

399. Smith v. L.A. County Bd. of Supervisors, 128 Cal. Rptr. 2d 700, 712 (Ct. App. 2002) (noting that the searches at issue are scheduled within a ten-day period after intake, must account for the applicant's work or education schedule, and are limited in scope).

400. Cf. Sanchez, 464 F.3d 916, 932 (Fisher, J., dissenting) ("By suggesting that welfare applicants may be treated the same as convicted criminals, the majority ignores the limits implicit-and explicit-in Griffin.").

401. Constitutional Law-Fourth Amendment, supra note 257, at 2003.

402. Audio file: Oral Argument, supra note 271, at 6:06-6:47 (remarks of Kleinfeld, J.). 
constitutional universe. The implausible implications of the holdings themselves, if applied outside the context of the poor, demonstrate the point.

The decisions rest on two propositions. First, the courts deem the state's fiscal interest in combating fraud and waste in the administration of a public benefits program as sufficiently compelling to justify the suspension of traditional Fourth Amendment protections. ${ }^{403}$ Second, the courts assert that applicants for such benefits have a sufficiently diminished expectation of privacy to preclude any complaint about the imposition of suspicionless search conditions. ${ }^{404}$ Consider the general application of these assertions. With respect to the state's interest in fiscal oversight, there is no distinction between public assistance to the poor and the myriad other state grants, subsidies, benefits, and tax deductions that extend to nearly every person in the nation. ${ }^{405}$ Necessarily, then, the holdings imply that virtually everyone is now subject to a special-needs search within whatever zone of privacy might relate to the verification of eligibility for the public benefit in question. (Certainly, if the home itself is subject to inspection on these grounds, no other physical space might possibly be exempt.) With respect to the privacy analysis, the holdings establish that a mere request for state aid ratchets down the applicant's privacy expectation so far that virtually no zone of privacy remains inviolate, provided that the state's intrusion reasonably relates to eligibility verification.

The general application of this reasoning would eviscerate the Fourth Amendment, as Judge Fisher notes in his Sanchez dissent:

The majority's conclusion . . . seems limitless and risks eroding the Fourth Amendment rights of various groups of people in this country. The government is a provider of countless benefits and services, many of which require verification of eligibility—such as disability benefits, Medicare and Medicaid benefits, veterans benefits, student financial aid grants and lunch subsidies for school students. If the majority is correct that a person's expectation of privacy in the home is reduced any time he or she has a relationship with the state that requires an eligibility determination, then there seems little to prevent the government from implementing a home visit program ... with respect to these beneficiaries as well. $^{406}$

To Judge Fisher's list might be added countless other subsidies, benefits, grants, and tax deductions that require recipients to meet specified eligibility criteria. ${ }^{407}$ For example, the rationale would permit school officials to conduct suspicionless home searches of all students seeking to enroll in any school district that requires verification of residency within its specified attendance boundaries. ${ }^{408}$ Internal Revenue Service

403. See supra notes $364-68$ and accompanying text.

404. See supra notes $395-99$ and accompanying text.

405. Constitutional Low-Fourth Amendment, supra note 257, at 2003 ("Every citizen is in a 'relationship' with the government, and fraud abounds in all governmental programs.").

406. Sanchez v. County of San Diego, 464 F.3d 916, 941 n.12 (9th Cir. 2006) (Fisher, J., dissenting).

407. See, e.g., Sanchez v. County of San Diego, 483 F.3d 965, 969 (9th Cir. 2007) (Pregerson, J., dissenting from denial of en banc rehearing); Constitutional Law-Fourth Amendment, supra note 257, at 2003.

408. See, e.g., Dunbar v. Hamden Bd. of Educ., 267 F. Supp. 2d 178, 182 (D. Conn. 2003) 
agents could likewise search the homes of all persons claiming a mortgage interest deduction to verify that the subject property is used as a primary or secondary residence. $^{409}$

In view of these implications, one must ask whether there is any basis to suspect that the Fourth Amendment is at actual risk of such an improbable diminution. The proposition receives no support from the Supreme Court's recent decisions, which have instead "'raised the bar' on the threshold requirement for a special needs search", 410 and expanded the Fourth Amendment's protection of the home in other contexts. ${ }^{411}$ Nor is the prospect plausible as a practical matter: it defies credulity to suggest that courts might permit every homeowner claiming the mortgage interest deduction to face a warrantless and suspicionless home search at the hands of the Internal Revenue Service. ${ }^{412}$ As the Supreme Court recently stressed, the Fourth Amendment must be construed to prohibit suspicionless intrusions "from becoming a routine part of American life. $\$ 413$

We are left, then, with the alternative explanation: the poor are simply different. The premise is not novel. Commentators have noted for decades that American law differentiates on the basis of class in its recognition of basic rights. ${ }^{414}$ As Julie Nice recently observed,

[The] forces of deconstitutionalization have constructed dual rules of constitutional law based on economic means. On one hand is the rule of law that respects the dignity of the haves and protects rights that benefit them .... On the other hand is the rule of law that refuses to protect rights in a manner that might protect or benefit the have-nots. This second-class rule of law adds insult to injury by constantly monitoring and invading the lives of the have-notscomprehensively scrutinizing and regulating both their work and family lives-

(noting that students "have no property right to attend school in Hamden unless they reside within that school district"); Acalanes Union High Sch. Dist., Frequently Asked Questions Regarding the Residency Verification Process (2009), available at http://www.acalanes. k12.ca.us/forms/residencyfaqs.pdf (requiring annual residency verification); Fremont Union High Sch. Dist., New Students (2009), http://www.fuhsd.org/REGnew (requiring all new students to verify residency); Fremont Union High Sch. Dist., Continuing Students (2009), $\mathrm{http} / / / \mathrm{www}$.fuhsd.org/REGcontinue (requiring all enrolled tenth graders to verify residency); $c f$. Martinez ex rel. Morales v. Bynum, 461 U.S. 321 (1983) (upholding state residency requirement for public school attendance against equal protection challenge).

409. See Treas. Reg. § 301.7605-1 (as amended in 1993); see also Wyman v. James, 400 U.S. 309, 343 (1971) (Marshall, J., dissenting); cf. Burkhart, supra note 2, at 270-72 (noting scale of homeowner subsidies).

410. Maclin, supra note 351, at 176.

411. See, e.g., Kyllo v. United States, 533 U.S. 27 (2001); see also Sanchez v. County of San Diego, 464 F.3d 916, 941 (9th Cir. 2006) (Fisher, J., dissenting).

412. Cf. Nice, supra note 2, at 656 ("Although general concern about the potential of fraud is not a sufficient basis for invading the privacy of most Americans under the Fourth Amendment, it has been accepted as sufficient when the home being invaded belongs to a poor mother receiving welfare to help support her family.").

413. City of Indianapolis v. Edmond, 531 U.S. 32, 42 (2000).

414. See, e.g., Jacobus tenBroek, California's Dual System of Family Law: Its Origin, Development, and Present Status (pts. 1-3), 16 STAN. L. REV. 257 (1964), 16 STAN. L. REV. 900 (1964), and 17 STAN. L. REV. 614 (1965). 
while simultaneously denying them the protection of legal rights to defend themselves within this regulatory regime. ${ }^{415}$

As Professor Nice notes, the contemporary welfare-search jurisprudence falls squarely within this tradition. ${ }^{416}$

While not confessing bias, the decisions at issue display it without apology or pretense. Thus the courts in Sanchez and Whitburn-like the Supreme Court before them in $\mathrm{Wyman}^{417}$-frankly embrace the stereotype of the immoral poor as a basis for analysis. During the Sanchez oral argument, for example, Judge Kleinfeld disdains the assertion that the state lacks sufficient interest to search the homes of all aid applicants, citing in rebuttal the apocryphal golf clubs and $\$ 5000$ television sets that await to be found in their living rooms. ${ }^{418}$ Writing for the Seventh Circuit in Whitburn, Judge Manion is only slightly less disdainful. To justify the state's "important interest in seeing that the funds received by the household [are] expended for their intended purpose," Judge Manion recounts that one plaintiff's "door was opened at about 9:30 a.m. by an adult male in his pajama bottoms" who then "shut the door in the field representative's face," while "at least two individuals" reported that another plaintiff had been living with her husband for some number of years. ${ }^{419}$ In a footnote, Judge Manion acknowledges that "[i]t is true that in these cases, both [plaintiffs] were able to convince the County that they were actually eligible for public assistance. But that does not change the fact that the County had good reasons to believe that neither applicant was eligible for benefits. ${ }^{, 420} \mathrm{He}$ continues:

We note these facts not because we have any interest in trivializing the social, moral, and economic difficulties that the recipients of public assistance must confront, but rather to illustrate that the state as well as the recipient and the caseworker 'not only [have] an interest but an obligation' to ensure proper use of funds entrusted from the public. ${ }^{421}$

Judge Manion declines to explain how two inflammatory anecdotes of disproven misconduct might illustrate the state's general interest in searching the homes of aid recipients, but the implication is clear enough. The poor live in a scandalous world of half-dressed deadbeats and secret spouses, face a corresponding and constant temptation to seek aid to which they are not entitled, and accordingly merit generalized suspicion in light of the "social, moral, and economic difficulties" that plague and corrupt their lives. It is a small step from this enduring stereotype to the otherwise inexplicable holdings in Sanchez, Whitburn, and Smith: why should courts demand compliance with the ordinary requirements of the Fourth Amendment when the state seeks to search the homes of an intrinsically culpable class?

415. Nice, supra note 2 , at 631 (footnotes omitted).

416. Id. at 652-55.

417. See supra notes $136-43$ and accompanying text.

418. Audio file: Oral Argument, supra note 271.

419. S.L. v. Whitburn, 67 F.3d 1299, 1308 (7th Cir. 1995).

420. Id. at 1308 n.5.

421. Id. at 1308 . 


\section{CONCLUSION}

In a blunt and disparaging dissent to the denial of en banc review in Sanchez, seven circuit court judges declare that San Diego's "shameful" search program is "nothing less than an attack on the poor" ${ }^{, 422}$ and that the panel decision upholding it "strikes an unprecedented blow at the core of Fourth Amendment protections." ${ }^{423}$ While the dissenters fairly condemn Sanchez for its singular departure from settled Fourth Amendment norms, ${ }^{424}$ their critique presumes that the comparison is germane to the majority's analysis. Were it so, the implications of Sanchez and related authorities would indeed be unprecedented, given the pedestrian rationale of fiscal accountability offered in defense of the challenged intrusions. All benefit programs entail virtually identical interests in fiscal integrity; if these common interests are "sufficiently vital"425 to support a suspicionless home search, then the practice is necessarily unlimited in its application to them. Considering the scale of government largesse, such an expansive conception of the search power would render the protections of the Fourth Amendment broadly irrelevant-a result that is irreconcilable with the rhetoric and practical reality of current jurisprudence. ${ }^{426}$

The implausibility of these implications demonstrates that contemporary welfaresearch decisions cannot be read within the traditional framework of the Fourth Amendment. These are not simply badly reasoned opinions that fail to account for their full reach, and their indifferent attempt to reconcile with prevailing doctrine is largely beside the point. The decisions instead proceed from a different, if implicit, premise: the poor are isolable as a subconstitutional class. Just as the Supreme Court in Wyman departed from otherwise applicable Fourth Amendment principles to craft and cabin a search doctrine for the poor alone, so too the contemporary decisions upholding aggressive welfare -search practices operate outside governing precedent to inflict their special burdens on a single class of litigants.

The judicial bias giving rise to this divided doctrine reflects a deeply rooted and enduring conception of the poor as morally bereft. The premise has animated public discourse since the European settlement of North America and served to exclude the poor from equal participation in our civic life for over two centuries. It has particularly direct application in the context of the Fourth Amendment's right to domestic privacy, which broadly limits the state's power to intrude within the home absent cause to

422. Sanchez v. County of San Diego, 483 F.3d 965, 969 (9th Cir. 2007) (Pregerson, J., dissenting from denial of en banc rehearing).

423. Id. at 966 . In addition to the seven judges joining in Judge Pregerson's dissent, Judge Alex Kozinski dissented separately. See id. at 969 (Kozinski, J., dissenting from denial of en banc rehearing).

424. See id. at $965-69$ (Pregerson, J., dissenting from denial of en banc rehearing).

425. Chandler v. Miller, 520 U.S. 305, 318 (1997).

426. Id. at 318-22; see supra notes 348-58; Sanchez, 483 F.3d at 969 (Pregerson, J., dissenting from denial of en banc rehearing) ("[W]e do not require similar intrusions into the homes and lives of others who receive government entitlements. The government does not search through the closets and medicine cabinets of farmers receiving subsidies. They do not dig through the laundry baskets and garbage pails of real estate developers or radio broadcasters. The overwhelming majority of recipients of government benefits are not the poor, and yet this is the group we require to sacrifice their dignity and their right to privacy."). 
suspect wrongdoing. By imputing to impoverished parents an innate risk of misconduct, in keeping with the abiding stereotype of the immoral poor, Sanchez and related authorities accept indigency as a surrogate for the individualized suspicion that otherwise would be required to justify the intrusions at issue. Once poverty is understood to necessarily imply some form of moral culpability, courts may then use it as a proxy for cause in authorizing state agents to indiscriminately rifle through the medicine cabinets, dresser drawers, and bedroom closets of all indigent aid applicants.

While any jurisprudence sanctioning such conduct is indeed "an assault on our country's poor, ${ }^{, 427}$ contemporary welfare-search decisions continue in a long tradition of judicial bias directed at the indigent. The archaic premise of the dissolute poor remains alive and well in American law, and we have a bifurcated Fourth Amendment to prove its enduring vitality.

427. Sanchez, 483 F.3d at 966 (Pregerson, J., dissenting from the denial of en banc rehearing). 